Topical Lime Application for the Management of Munitions Constituents Following Blow-In-Place Operations

Jared L. Johnson, Jeffrey L. Davis, and Catherine C. Nestler

June 2010 


\section{Topical Lime Application for the Management of Munitions Constituents Following Blow-In-Place Operations}

Jared L. Johnson and Jeffrey L. Davis

Environmental Laboratory

U.S. Army Engineer Research and Development Center

3909 Halls Ferry Road

Vicksburg, MS 39180-6199

Catherine C. Nestler

Applied Research Associates

112 Monument Place

Vicksburg, MS 39180

Final report

Approved for public release; distribution is unlimited.

Prepared for U.S. Army Corps of Engineers

Washington, DC 20314-1000 


\begin{abstract}
Blow-in-place operations provide a proven method of handling unexploded ordnance, but they also deliver significant amounts of munitions constituents residues to the environment. These residues may persist and affect environmental sustainability on training ranges. Alkaline hydrolysis is a well-established method for the destruction of explosives compounds. The objective of this study was to measure the efficacy of onsite treatment of munitions constituents with hydrated lime following blow-in-place operations. Samples taken immediately following topical application of hydrated lime demonstrate that lime does have an immediate effect on RDX concentration. However, munitions constituents residues unaffected by lime treatment remained at the end of the study, probably because of poor contact between munitions constituents residues and hydrated lime. This study highlighted three challenges to consider as technology development moves forward on alkaline treatment of munitions constituents. First, inconsistent RDX concentrations obscured the results of the field study. Second, the application method will make an important impact on the success of the treatment. Finally, application rates will need to be tailored to individual applications so that enough alkaline material is delivered to effect complete destruction of the munitions constituent residues of concern.
\end{abstract}

DISCLAIMER: The contents of this report are not to be used for advertising, publication, or promotional purposes. Citation of trade names does not constitute an official endorsement or approval of the use of such commercial products. All product names and trademarks cited are the property of their respective owners. The findings of this report are not to be construed as an official Department of the Army position unless so designated by other authorized documents. 


\section{Contents}

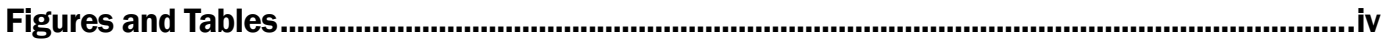

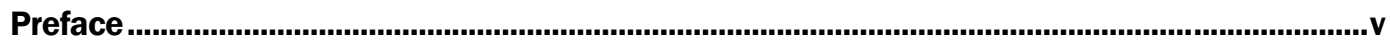

Unit Conversion Factors.........................................................................................................................vi

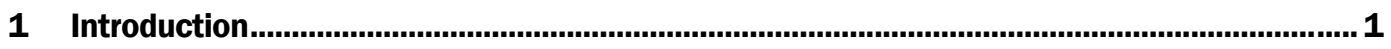

2 Materials and Methods................................................................................................ 3

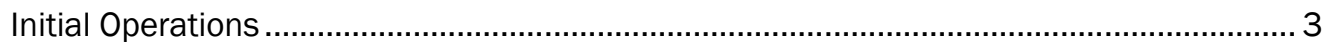

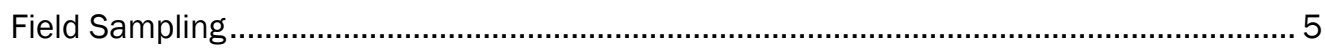

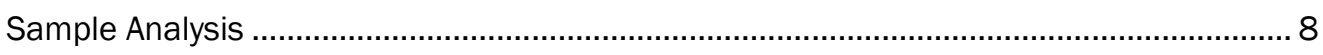

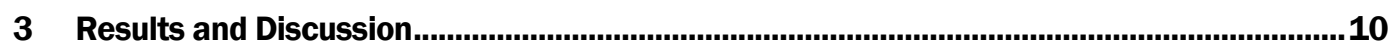

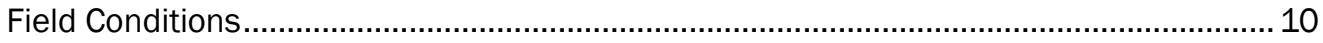

Concentrations of Munitions Constituents in Soils ........................................................ 11

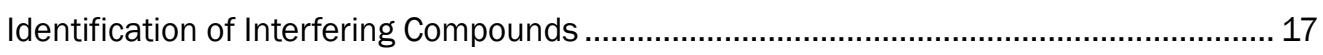

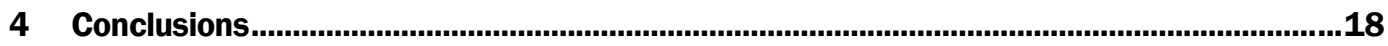

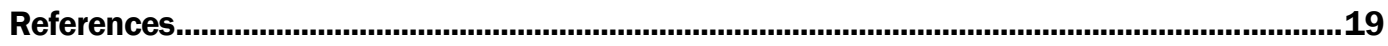

Appendix A

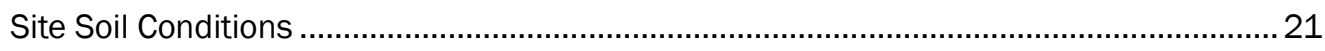

$\mathrm{pH}$

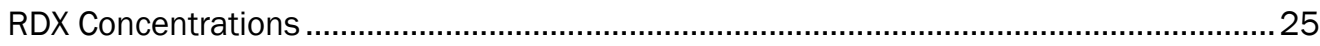

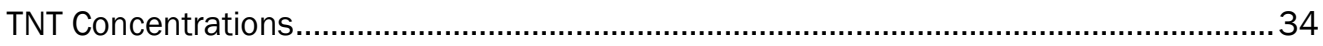

\section{Report Documentation Page}




\section{Figures and Tables}

\section{Figures}

Figure 1. Plan view of test plot layout.

Figure 2. $60 \mathrm{~mm}$ mortar round prepared for blow-in-place operations. .............................................. 4

Figure 3. Site \#4 after treatment with $227 \mathrm{~kg}$ of hydrated lime

Figure 4. Sampling areas for BiP sites. .................................................................................... 6

Figure 5. Taking a core from the soil surface. ........................................................................... 7

Figure 6. Pushing a soil core out of the tool. ................................................................................ 7

Figure 7. Recorded precipitation and normal totals for Redstone Arsenal, AL............................... 10

Figure 8. RDX concentrations at sites \#1 (control) and \#4 (treated) from 27 Oct 2004................. 11

Figure 9. RDX Concentrations on site \#1 (control) during the duration of the study......................... 13

Figure 10. RDX concentrations on site \#4 (treated) during the duration of the study. ..................... 14

Figure 11. Total estimated mass of RDX per site on treated and control sites over the

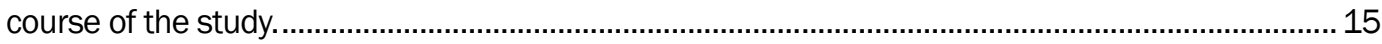

Figure 12. Total estimated mass of TNT per site on treated and control sites over the course of the study.

\section{Tables}

Table A1. Test plot soil constituent analysis. ............................................................................... 21

Table A2. pH at the soil surface on site \#1 (control) by sampling area............................................ 22

Table A3. pH at the soil surface on site \#2 (control) by sampling area............................................. 22

Table A4. pH at the soil surface on site \#3 (control) by sampling area............................................ 23

Table A5. pH at the soil surface on site \#4 (treated) by sampling area............................................ 23

Table A6. pH at the soil surface on site \#5 (treated) by sampling area............................................. 24

Table A7. pH at the soil surface on site \#6 (treated) by sampling area. ........................................... 24

Table A8. RDX concentrations at the soil surface on site \#1 (control) by sampling area. .................25

Table A9. RDX concentrations at the soil surface on site \#2 (control) by sampling area. ................ 25

Table A10. RDX concentrations at the soil surface on site \#3 (control) by sampling area............... 26

Table A11. RDX concentrations at the soil surface on site \#4 (treated) by sampling area. ............. 26

Table A12. RDX concentrations at the soil surface on site \#5 (treated) by sampling area. ............. 27

Table A13. RDX concentrations at the soil surface on site \#6 (treated) by sampling area. ............. 27

Table A14. TNT concentrations at the soil surface on site \#1 (control) by sampling area.................34

Table A15. TNT concentrations at the soil surface on site \#2 (control) by sampling area.................34

Table A16. TNT concentrations at the soil surface on site \#3 (control) by sampling area.................35

Table A17. TNT concentrations at the soil surface on site \#4 (treated) by sampling area.................35

Table A18. TNT concentrations at the soil surface on site \#5 (treated) by sampling area................36

Table A19. TNT concentrations at the soil surface on site \#6 (treated) by sampling area...............36 


\section{Preface}

The work reported here was conducted at the U.S. Army Engineer Research and Development Center (ERDC), Vicksburg, MS. Funding for this project was provided through the Environmental Quality Technology Program.

The work in this report was part of an effort to develop management options for munitions constituents in soils and water on military training ranges. This report was prepared by J ared L. J ohnson and Dr. J effrey L. Davis of the Environmental Engineering Branch, Environmental Laboratory (EL), ERDC, and Catherine Nestler, Applied Research Associates, Vicksburg, MS. Chemical analyses were performed by the Environmental Chemistry Branch of ERDC. The authors gratefully acknowledge the technical assistance provided by Deborah Ragan, LeeAnn Riggs, J ulie McClure, and Thomas Borrowman.

This study was conducted under the direct supervision of Dr. Pat Deliman, Chief, Environmental Engineering Branch, and Dr. Richard E. Price, Chief, Environmental Processes and Engineering Division, and under the general supervision of Dr. Beth Fleming, Acting Director, EL. The Commander and Deputy Director of ERDC is COL Gary E. J ohnston. The Director is Dr. J effery P. Holland. 


\section{Unit Conversion Factors}

\begin{tabular}{|l|c|l|}
\hline Multiply & By & To Obtain \\
\hline feet & 0.3048 & meters \\
\hline inches & 0.0254 & meters \\
\hline
\end{tabular}




\section{Introduction}

The Army is committed to maintaining a professional and well-trained fighting force. Live fire test and training ranges make an integral contribution to that commitment by maintaining Army readiness. Environmental stewardship is also integral to all facets of the Army mission (U.S. Army 2004). Live-fire and blow-in-place operations have been shown to deliver significant amounts of munitions constituents (MC) residues to the environment (Pennington et al. 2003, Hewitt et al. 2005). These residues may persist and affect environmental sustainability on training ranges. A case in point is the RDX contamination of a sole-source drinking water aquifer on Cape Cod, MA (Clausen et al. 2004). Maintaining both readiness and environmental sustainability on Army training ranges necessitates proper management of MCs.

When human health and safety is a concern, blow-in-place (BiP) operations provide a proven method of handling unexploded ordnance (UXO). Typically a donor charge of composition 4 (C4) is placed against the UXO casing and used to initiate detonation of the main charge. Studies have shown that $\mathrm{BiP}$ operations deliver significantly more $\mathrm{MC}$ residues to the environment than live-fire operations (Hewitt et al. 2005). These residues are found on the surface in the immediate area of $\mathrm{BiP}$ operations. Management of MC residues immediately following BiP operations may mitigate the persistent effects of MC deposition and eliminate the need for more extensive environmental cleanup at a later date.
Alkaline hydrolysis is a well-established method for the destruction of explosives compounds (J ankowsky 1891, Urbanski 1964). Previous studies have shown that hydrated lime effectively destroys the explosive compounds 1,3,5-hexahydro-1,3,5-trinitrotriazine (RDX) and 2,4,6- trinitrotoluene (TNT) in contaminated soil samples (Hansen et al. 2003, Brooks et al. 2003). These studies demonstrated that the chemical process of alkaline hydrolysis is rapid and efficient. Physical processes become the controlling factor when engineering hydrated lime technology to manage $\mathrm{MC}$ residues on training ranges. Studies in soil mesocosms demonstrated that topical addition of hydrated lime does not result in high $\mathrm{pH}$ below the top two inches of soil (Brooks et al. 2003). Soil acts as a significant hydroxide sink, so in a soil environment, hydrated lime must be in direct 
contact with $\mathrm{MC}$ residues to affect destruction. Since $\mathrm{MC}$ residues are deposited on the surface following BiP operations, they may be treated immediately following operations with a topically applied amendment. This study focused on treating the localized residues remaining after $\mathrm{BiP}$ operations by topically applying hydrated lime. The objective of this study was to quantify on-site treatment of MCs following BiP operations. The results will aid in the development of an alkaline treatment technology for use on training ranges.

A test area was defined at Redstone Arsenal, AL, to perform six sets of BiP operations. Three of the resulting BiP craters were treated with hydrated lime, and three craters were left untreated as a control. Each of the craters was sampled over a six-month period to quantify the explosives concentration distribution over time. 


\section{Materials and Methods}

\section{Initial Operations}

BiP operations were performed on 26 Oct 2004 on a plot set aside at Test Area 6, Redstone Arsenal, AL. The plot is a well-drained grassy area bordered on the west and south sides by a commercial timber stand of mature loblolly pines. Access roads border the north and east sides of the test plot. The plot lies within the safety cone of an antitank missile test range, but there is no record of munitions impact within the test plot. Prior to moving forward with the study, Test Area 6 completed an environmental risk assessment, finding no significant impact as a result of the activities relating to the study. As part of commercial timber management activities, the plot was burned off during the spring of 2004 . J ust prior to operations, grass on the test plot was tilled under by a disc cultivator, and operations were carried out on bare earth.

The test plot consisted of six sites available for BiP operations as detailed in Figure 1. Sites \#1, 2, and 3 were placed with centers $35 \mathrm{~m}$ apart on the west side of the test plot. Sites \#4, 5, and 6 were also each $35 \mathrm{~m}$ apart on the east side of the test plot. A grassy strip approximately $50 \mathrm{~m}$ wide was left between the west and east sides of the test plot. The BiP setup is shown in Figure 2. At each test site, five 60-mm mortar rounds were sequentially blown in place, each using one block ( $565 \mathrm{~g}$ ) of $\mathrm{C} 4$ placed directly on the casing. The $\mathrm{C} 4$ donor charge consisted of 91 percent $\mathrm{RDX}$ and 9 percent plasticizer. Detonations were instigated using two blasting caps with 5minute fuses. The $60-\mathrm{mm}$ mortar rounds contained $360 \mathrm{~g}$ of composition $\mathrm{B}$ (CompB). CompB consists of 60 percent RDX, 39 percent TNT, and 1 percent wax. In total, $3.9 \mathrm{~kg}$ of RDX and $0.7 \mathrm{~kg}$ of TNT were detonated at each BiP site. By visual inspection, all detonations were high order. 


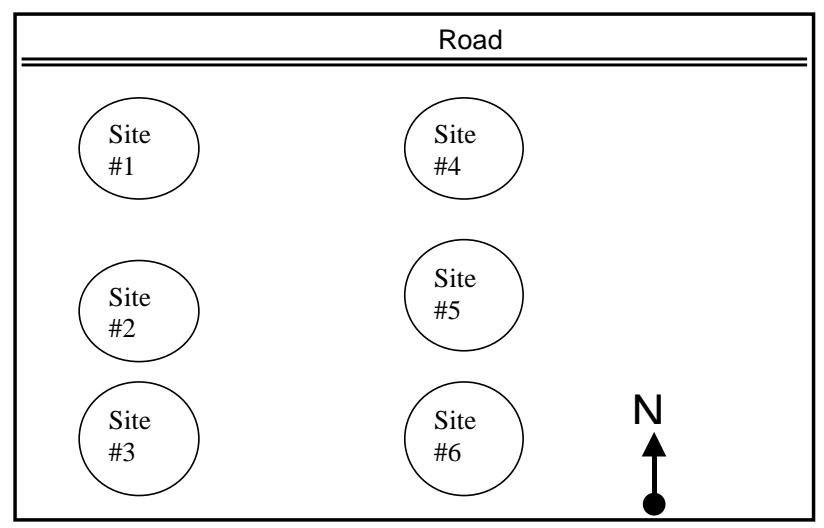

Figure 1. Plan view of test plot layout.

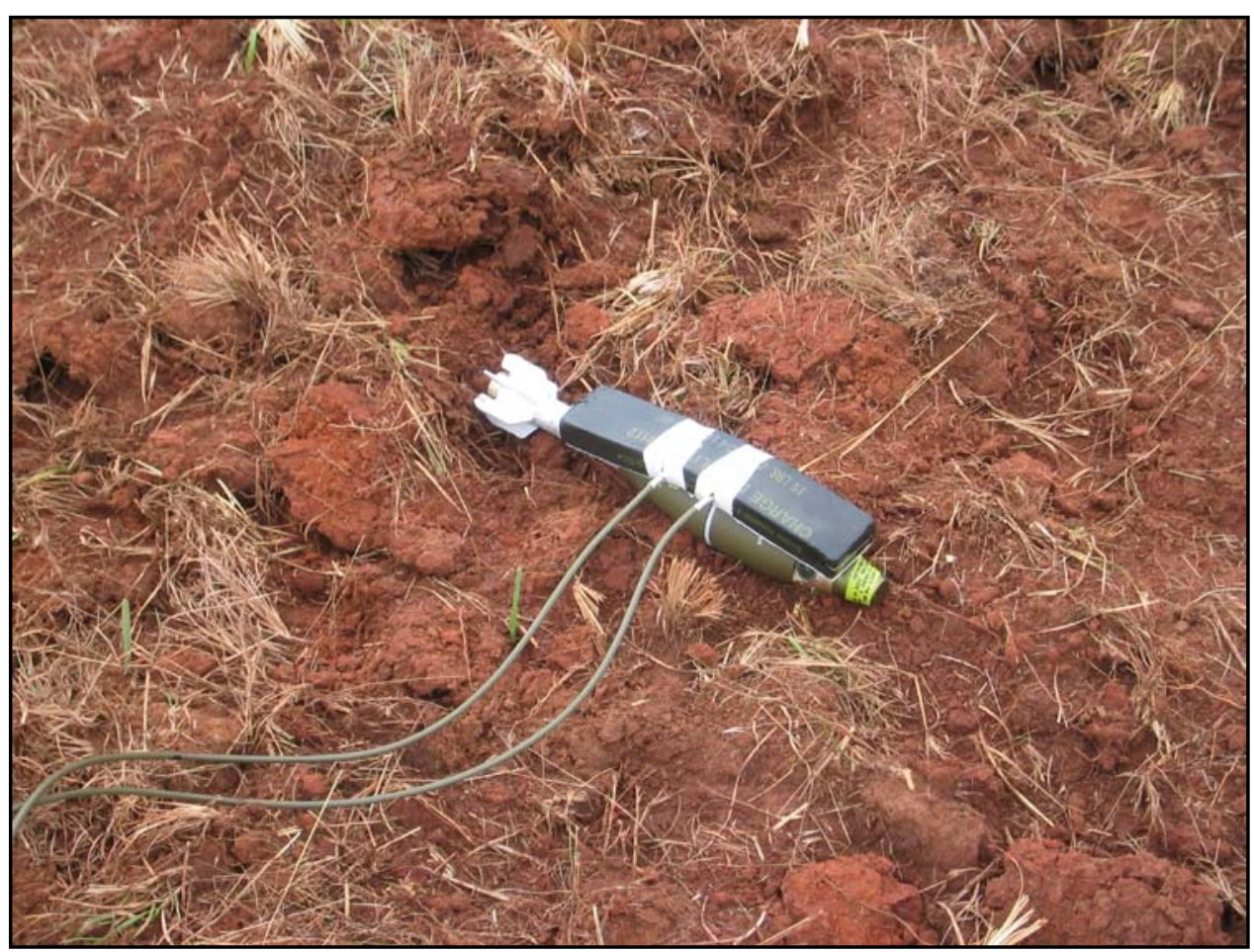

Figure $2.60 \mathrm{~mm}$ mortar round prepared for blow-in-place operations.

Following BiP operations, sites \#4, 5, and 6 were each treated with hydrated lime. Site \#4 is shown in Figure 3 after treatment. High-calcium hydrated lime (Brenntag Inc., Madison, AL) was applied with a 5-ft drop spreader (Garber Seeder Co., South Charleston, $\mathrm{OH}$ ) pulled behind an allterrain vehicle. On each of the treated sites, $227 \mathrm{~kg}$ of lime was applied across a 30- $\times 30-\mathrm{m}$ square centered on the BiP crater. Because of the depth of disturbance, lime was applied manually in the craters. Effort was made visually to apply the lime as evenly as possible, with a resulting average application of 2.52 tonne/ hectare. 


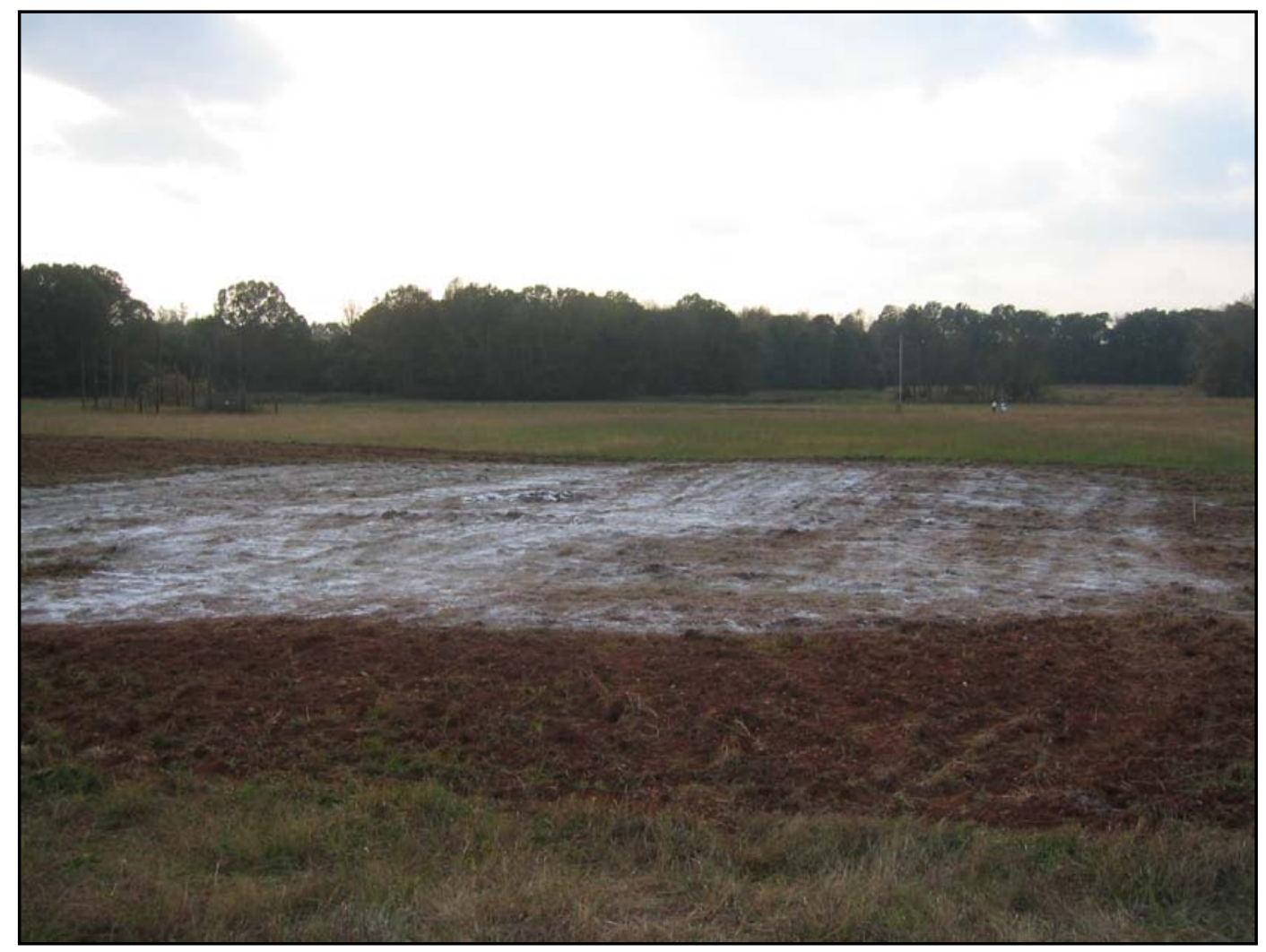

Figure 3. Site \#4 after treatment with $227 \mathrm{~kg}$ of hydrated lime.

\section{Field Sampling}

Each site on the test plot was divided into 15 soil sampling areas for explosives determination as detailed in Figure 4. The sites were laid out as a circle of radius $15 \mathrm{~m}$ centered on the BiP crater, with sampling areas subdivided on an annular pattern within the circle. A uniform sample numbering system of the form YYMMDD.S.AA.A/B was used throughout the study. Under this system, YYMMDD is a date stamp indicating the date of sampling, S denotes the BiP site number, AA denotes the sampling area number, and either an $\mathrm{A}$ or a B on the end indicates duplicate samples. 


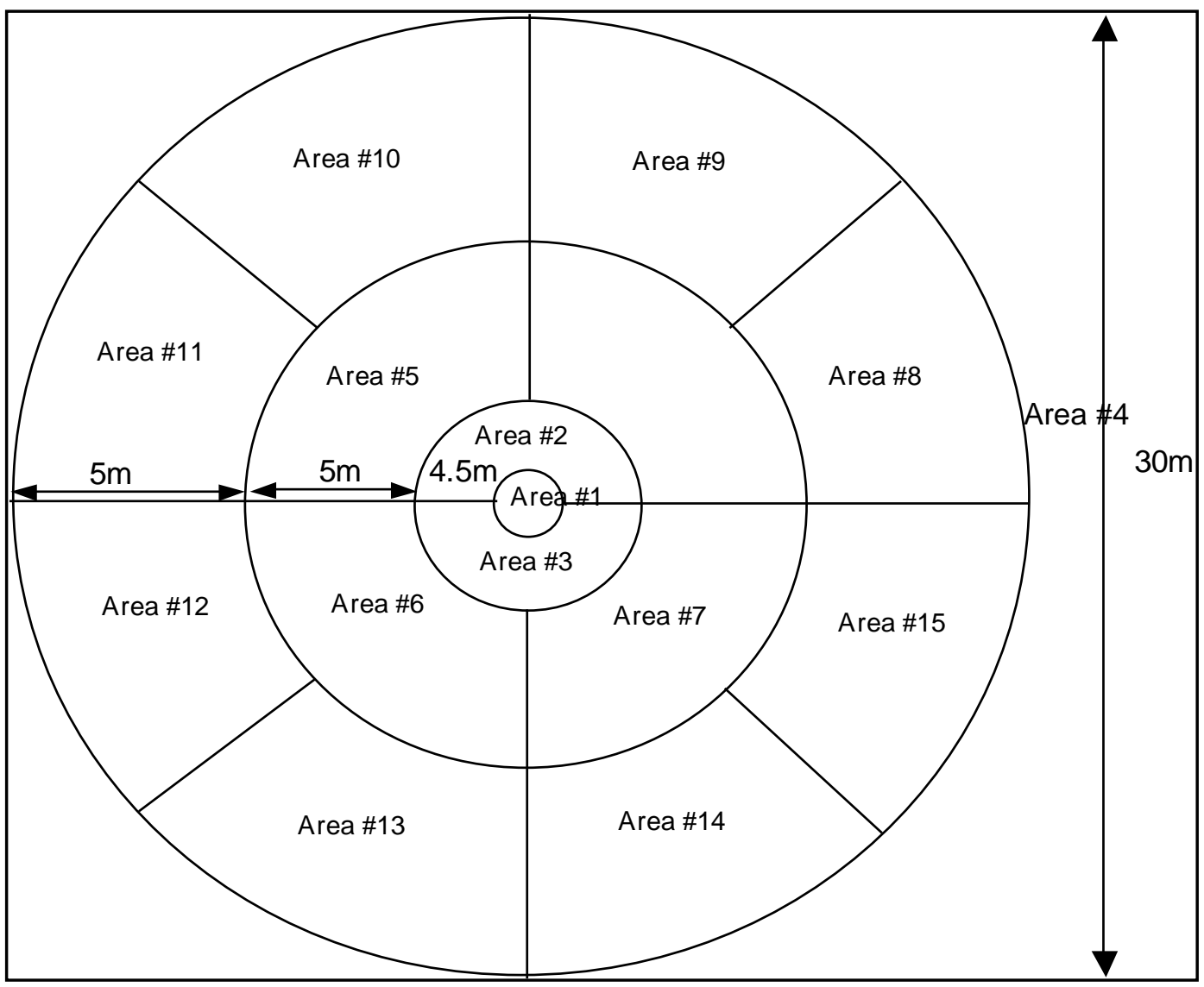

Figure 4. Sampling areas for BiP sites.

Representative soil surface sampling was accomplished using coring tools developed by ERDC/ CRREL (Walsh 2004) and built by the Department of Public Works, Vicksburg. The sampling procedure is shown in Figures 5 and 6. The coring tools consisted of a sharpened length of 2-in.-ID steel pipe attached to a handle. The tool was pushed into the ground and pulled away to remove a 2-in.-diameter by approximately 1-in.-deep soil core. A 2-in.-diameter by 8-in.-long steel plug was used to push the soil core out of the top of the core tool, and the core was placed in a 1-gal. plastic bag. Each sample consisted of 25 composited 2-in.-diameter by 1-in.-deep soil cores taken randomly across a sampling area. The composite samples were sealed in 1-gal. plastic bags and brought to ERDC/ EL, where they were stored at $4^{\circ} \mathrm{C}$ awaiting analysis. 


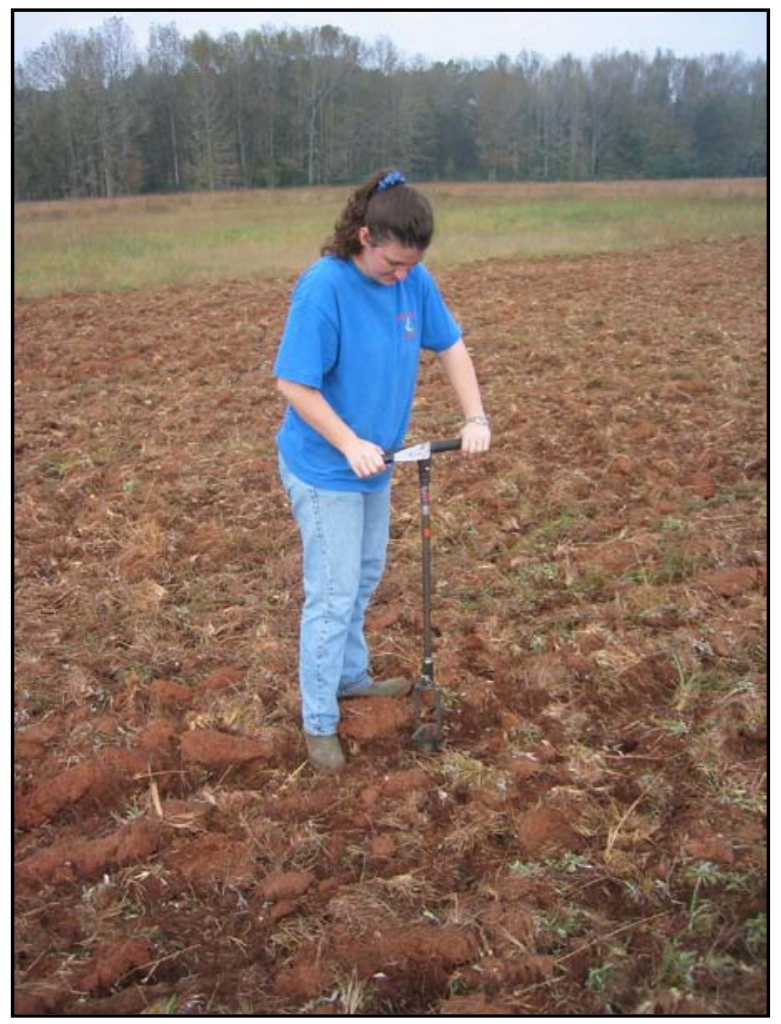

Figure 5. Taking a core from the soil surface.

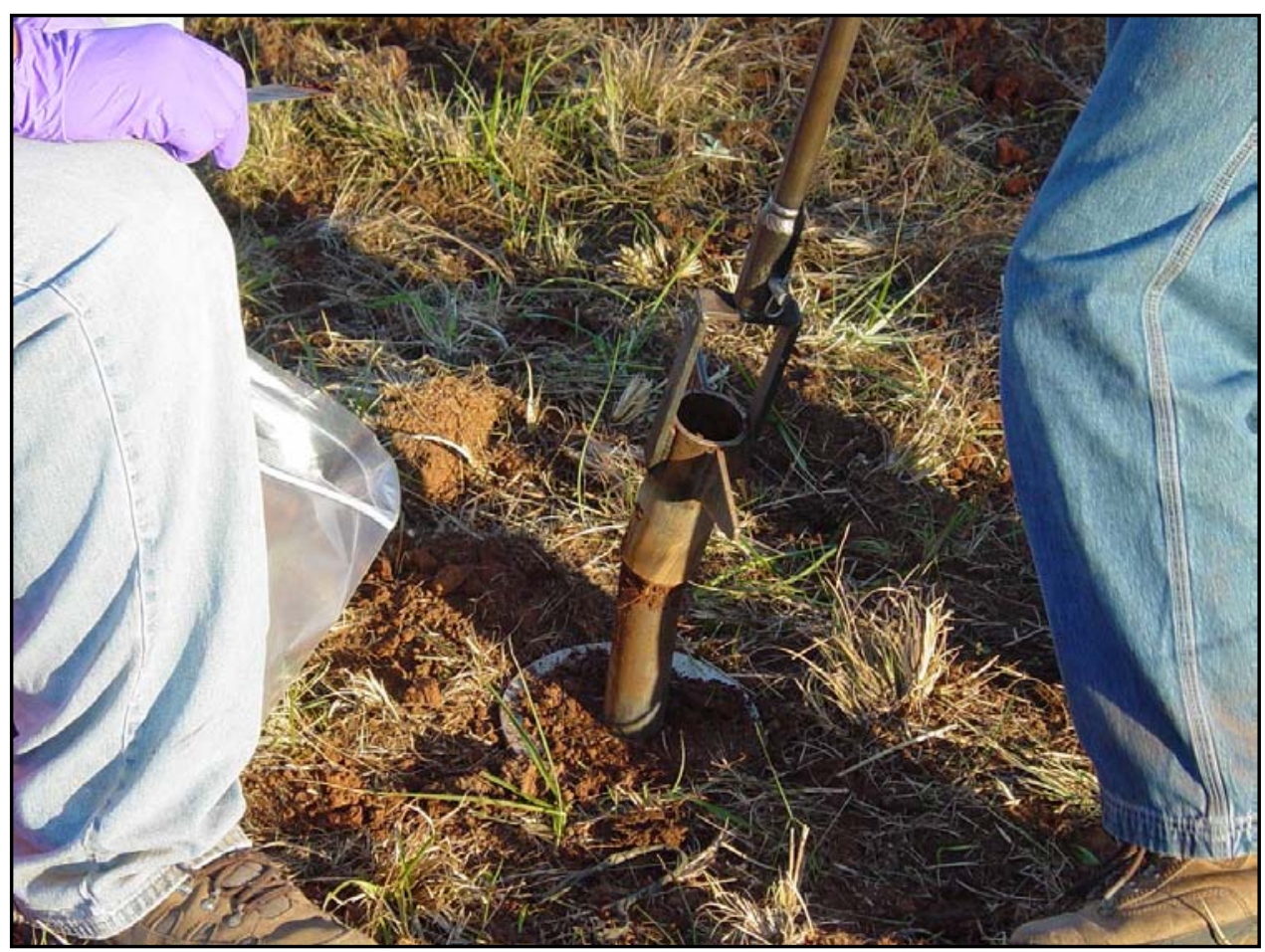

Figure 6. Pushing a soil core out of the tool. 
Immediately following BiP operations and lime application, BiP sites \#1, 4, and 5 were sampled with 100 percent duplication. Rain prevented further sampling on 28 Oct 2004 . BiP sites \#6, 2, and 3 were sampled with 100 percent duplication on 16-17 Nov 2004, while sites \#1, 4, and 5 were sampled with 10 percent duplication. Further sampling instances with 10 percent duplication were completed on 13 Dec 2004, 19 J an 2005, 23 Feb 2005, 29 Mar 2005, and 26-27 Apr 2005. Rain on 27 Apr 2005 prevented sites \#2 and 3 from being sampled. The study encompassed a total sampling period of six months.

\section{Sample Analysis}

Sample preparation began by removing composite samples from the plastic bags onto 19- $\times 24$-in. stainless steel trays. Pebbles, roots, twigs, and pieces of grass were manually removed, and the large clumps of dirt were broken up to spread each sample evenly over the surface of the tray. At this point a 10-g subsample was removed for a $\mathrm{pH}$ measurement, and a 15- to 25-g subsample was removed for moisture analysis. The samples were allowed to air dry and then placed in 5.0-L Roalox grinding jars with approximately $1 / 2$ L of $1 / 2$-in. high-density alumina beads (Sepor, Inc. Wilmington, CA). The jars were placed on a two-tier jar roll drive (Sepor, Inc., Wilmington, CA) and rotated for six hours until the samples were the consistency of flour. Each ground sample was passed through a \#10 sieve to remove the alumina beads and any remaining rocks or twigs, and it was again spread out on a 19- $\times 24$-in. stainless steel tray. Two 10-g subsamples were removed from the ground samples, and the remaining material was stored in a 1-L amber glass jar. Subsamples consisted of multiple $<1.0$-g increments taken from random locations on the tray. One subsample from each ground sample was measured for $\mathrm{pH}$, and the other was placed in an amber glass $40-\mathrm{mL}$ vial awaiting explosives analysis.

For explosives analysis, a 10-g subsample was extracted with $20 \mathrm{~mL}$ of acetonitrile for 18 hours in an ultrasonic bath. Extracted samples were centrifuged at $1100 \mathrm{rpm}$ for 15 minutes, and the supernatant was decanted and passed through a $0.45-\mu \mathrm{m}$ syringe filter. The resulting acetonitrile extract was analyzed for explosives compounds according to SW846 method 8330 (USEPA 1994a) using a Waters 486 HPLC with a tunable absorbance detector. A broad hump of co-eluting compounds initially prevented the identification of RDX in HPLC analysis. Since the soil samples were collected from the surface, this was assumed to be interference from plant compounds. A cleanup procedure was 
implemented that had previously been described for analysis of explosives in plant tissue (Larson et al. 1998, 1999). Most samples were below HPLC detection limits of $20 \mu \mathrm{g} / \mathrm{kg}$, so further analysis was performed according to SW846 method 8091 (USEPA 1994b) using a Hewlett Packard 6890 GC with electron capture detection to provide a lower detection limit of $2.0 \mu \mathrm{g} / \mathrm{kg}$. MC compound identifications were confirmed by LC/ MS.

Interfering compounds were removed by passing the filtered extract through columns of Florisil (Eastman Fine Chemicals, Rochester, NY) and neutral alumina (Fisher Scientific, Fair Lawn, NJ ). Cleanup columns were prepared in 15-cm disposable glass pipettes with a small piece of glass wool at the bottom. On top of the glass wool was placed $0.5 \mathrm{~g}$ of Florisil, and $0.5 \mathrm{~g}$ of neutral alumina was placed on top of the Florisil. Then $5.0 \mathrm{~mL}$ of acetonitrile extract was filtered through the column, followed by $5.0 \mathrm{~mL}$ of pure acetonitrile. The resulting extract was analyzed for explosives compounds according to SW846 methods 8330 and 8091. Spike recoveries from this method are greater than 90 percent with the exception of HMX, for which recoveries as low as 30 percent have been observed (Larson et al. 1998). 


\section{Results and Discussion}

\section{Field Conditions}

BiP operations and subsequent sampling events were performed between 26 Oct 2004 and 27 Apr 2005. Rainfall totals for each month of the study are detailed in Figure 7 along with the monthly normal precipitation totals (NOAA 2002). Over the course of the study, $86.39 \mathrm{~cm}$ of rain fell at the test plot. November and December saw the heaviest monthly rainfall with 20.09 and $23.75 \mathrm{~cm}$, respectively. These two months were above normal for rainfall, but the remaining four months of the study saw normal or below-normal precipitation.

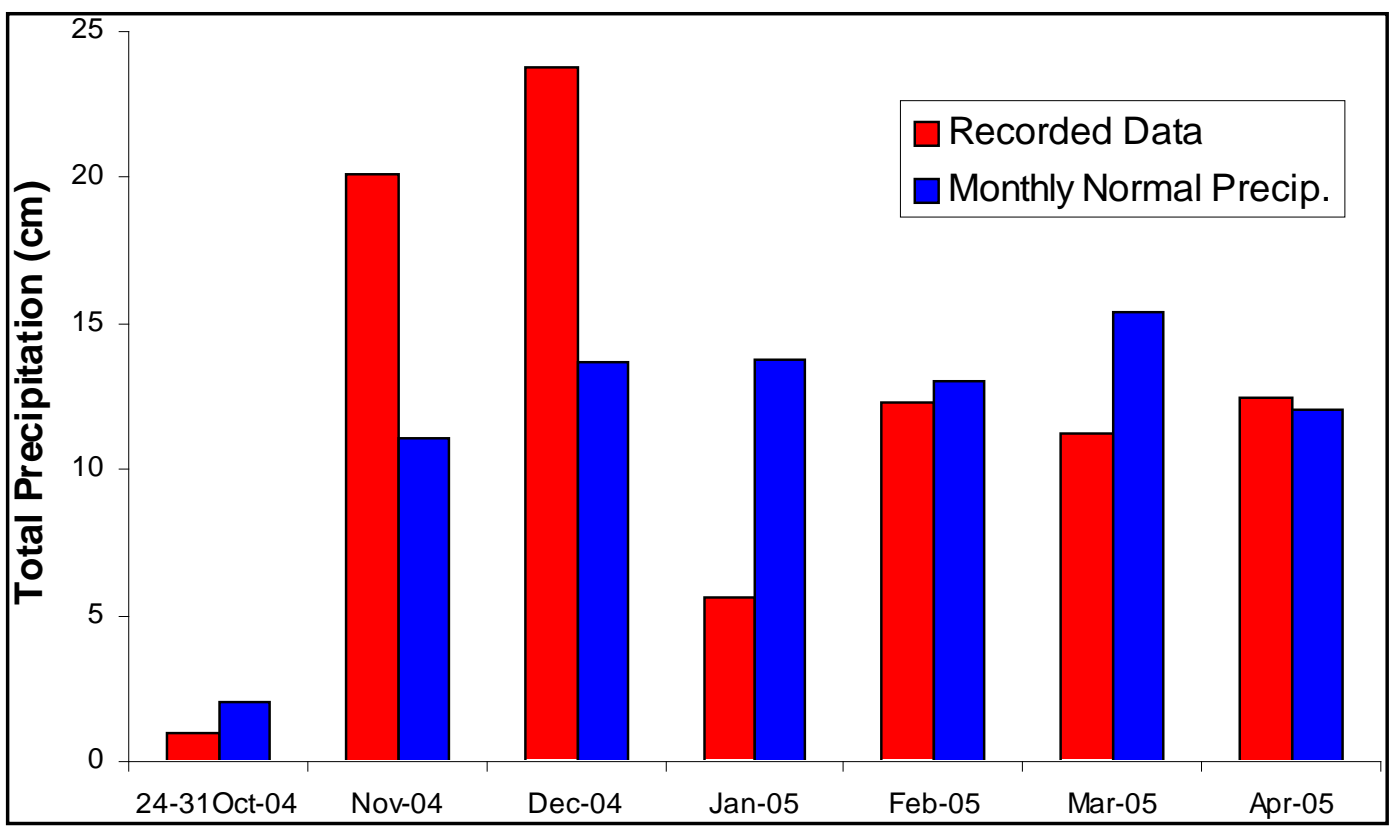

Figure 7. Recorded precipitation and normal totals for Redstone Arsenal, AL.

Surface soils at the test site are of the Decatur silty clay series (USDA/ NCRS 1958) characterized as severely eroded and undulating. A site soil constituent analysis is included in Appendix A. On the untreated sites the median $\mathrm{pH}$ for the top $1 \mathrm{in}$. of soil was $5.85(\mathrm{n}=311)$. Sites treated with hydrated lime exhibited a median $\mathrm{pH}$ of $7.63(\mathrm{n}=375)$ in the top inch. From month to month, the soil pH did not change significantly in either the treated or untreated sites. Complete $\mathrm{pH}$ results by sampling area are detailed in Appendix A. By the end of the study most of the hydrated 
lime had disappeared from the soil surface, and mixed grasses had reestablished on both the treated and control sites.

\section{Concentrations of Munitions Constituents in Soils}

Sites \#1, 4, and 5 were sampled immediately following BiP operations and lime application on the 27 and 28 Oct 2004. Rain on 28 Oct prevented complete sampling of sites \#2, 3, and 6. Each site was subsequently sampled completely on 16-17 Nov 2004, 13 Dec 2004, 19 J an 2005, 23 Feb 2005, and 29 Mar 2005. Sites \#1, 4, 5, and 6 were sampled on 26-27 Apr 2005 before rain again cut short sampling.

Representative RDX results from control and treated sites are detailed for 27 Oct 2004 in Figure 8. Sites \#1 and \#4 contained 10 and 11 sampling areas, respectively, in which the concentration of RDX in the top $1 \mathrm{in}$. of soil was greater than $2 \mu \mathrm{g} / \mathrm{kg}$. Site \#5 contained 12 sampling areas with RDX concentrations above $2 \mu \mathrm{g} / \mathrm{kg}$. An estimated total mass of $45 \mathrm{mg}$ of $\mathrm{RDX}$ was deposited on the one control site sampled on 27 Oct (site \#1). By this measure each BiP round deposited approximately $9 \mathrm{mg}$ of RDX, 0.0012 percent of the total RDX detonated, to the environment. By contrast, live fire tests have demonstrated an average RDX deposition of 0.000034 percent for proximity-fused $60-\mathrm{mm}$ mortar rounds (Hewitt et al. 2005). Samples taken immediately following lime application on the treated sites (sites \#4-6) yielded an estimated total mass of $25 \mathrm{mg}$ of RDX per site.

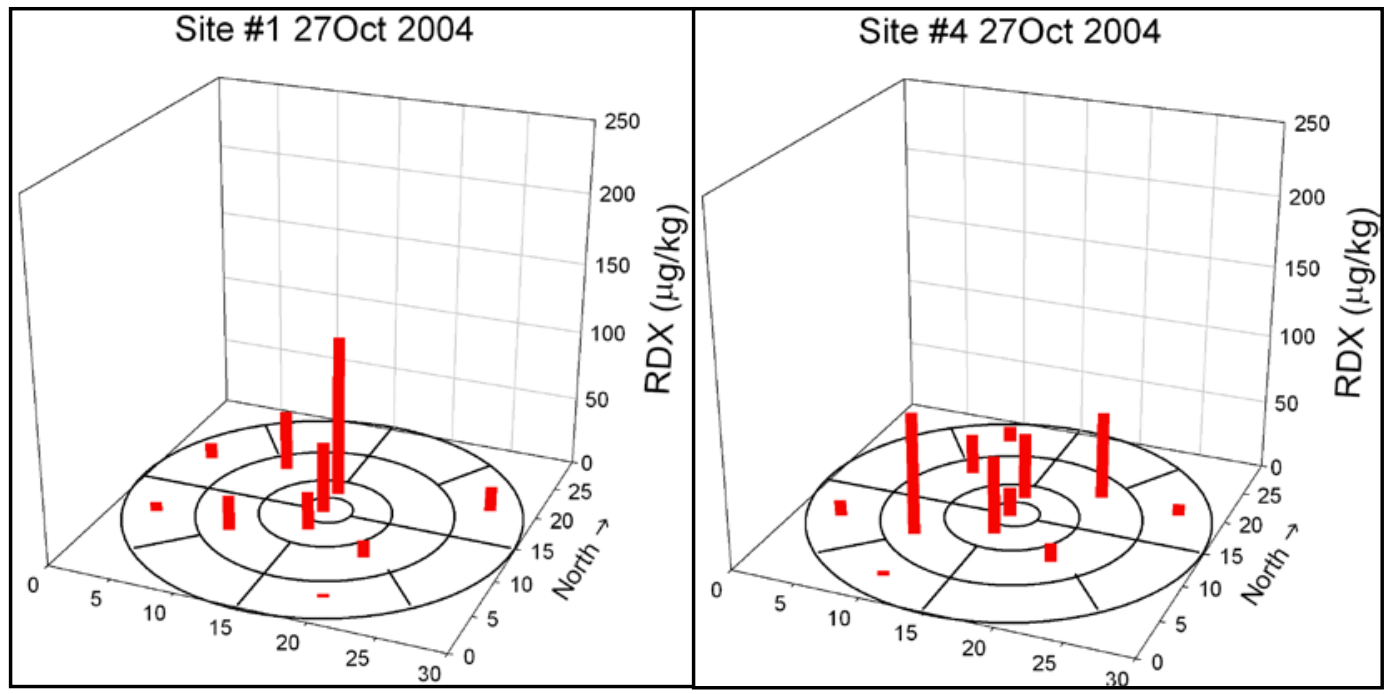

Figure 8. RDX concentrations at sites \#1 (control) and \#4 (treated) from 27 Oct 2004. 
Figure 9 details RDX concentrations from a representative control site (site \#1) over the duration of the study. Complete RDX concentration results are given in Appendix A. Initially, 10 sampling areas contained a detectable amount of RDX (greater than $2 \mu \mathrm{g} / \mathrm{kg}$ ). One month after the initial BiP operations, only 4 areas were found to have detectable concentrations of RDX. Over the course of the study, the amount of RDX measured varied, but there was an ongoing process by which RDX disappeared from the soil surface. Processes affecting disappearance in the control sites may include transport through the vadose zone, uptake by plants, photodegradation, and biological degradation. These processes were difficult to quantify given the high variance in the RDX concentrations from month to month. A variance was estimated for each duplicate sample and pooled with other estimated variances to yield a pooled variance for each sampling event. For 27-28 Oct, the pooled logvariance was $0.65 \mu \mathrm{g} / \mathrm{kg}$, resulting in an upper 95 percent confidence limit of $395 \mu \mathrm{g} / \mathrm{kg}$ for a sampling area measuring $52 \mu \mathrm{g} / \mathrm{kg}$ RDX. Ensuing months exhibited higher pooled variances due to fewer degrees of freedom in the estimation. As a result, with fewer degrees of freedom at each sampling instance, it became impossible to make a statistically significant determination of the disappearance rate for RDX.

Figure 10 details RDX concentrations from a representative treated site (site \#4) over the duration of the study. Like the results for the untreated sites, there was an immediate dropoff in the amount of RDX present from October to November. The greatest difference between this treated site and the control example is that by February no RDX could be found on the site. The complete disappearance of RDX from this treated site by February suggests that topical lime application increased the rate of disappearance of RDX. However, RDX was still present at other treated sites at the end of the study. The variance was great enough for the treated sites to prevent concluding that the difference in disappearance rates between treated and control sites was statistically significant. 


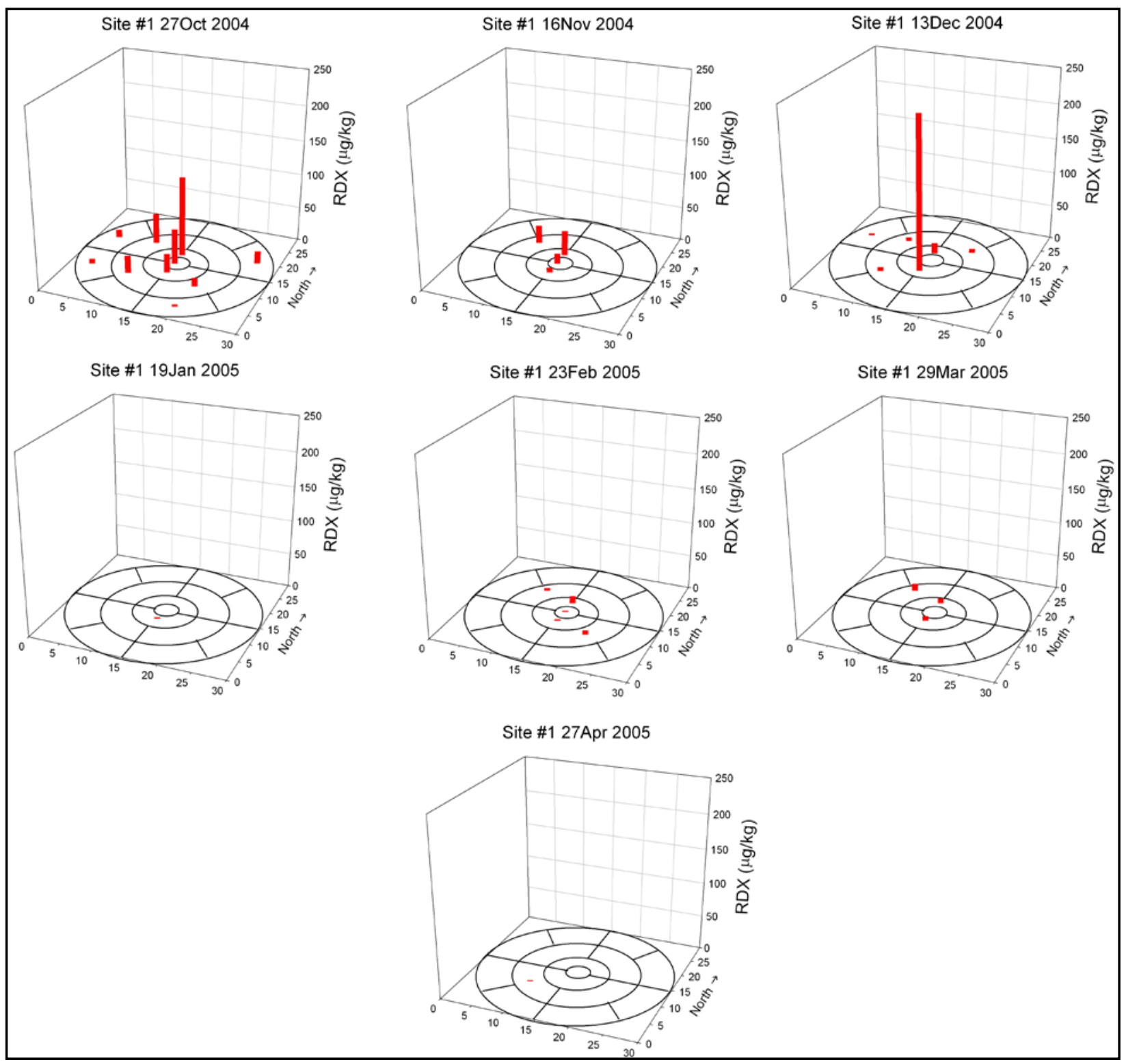

Figure 9. RDX Concentrations on site \#1 (control) during the duration of the study. 


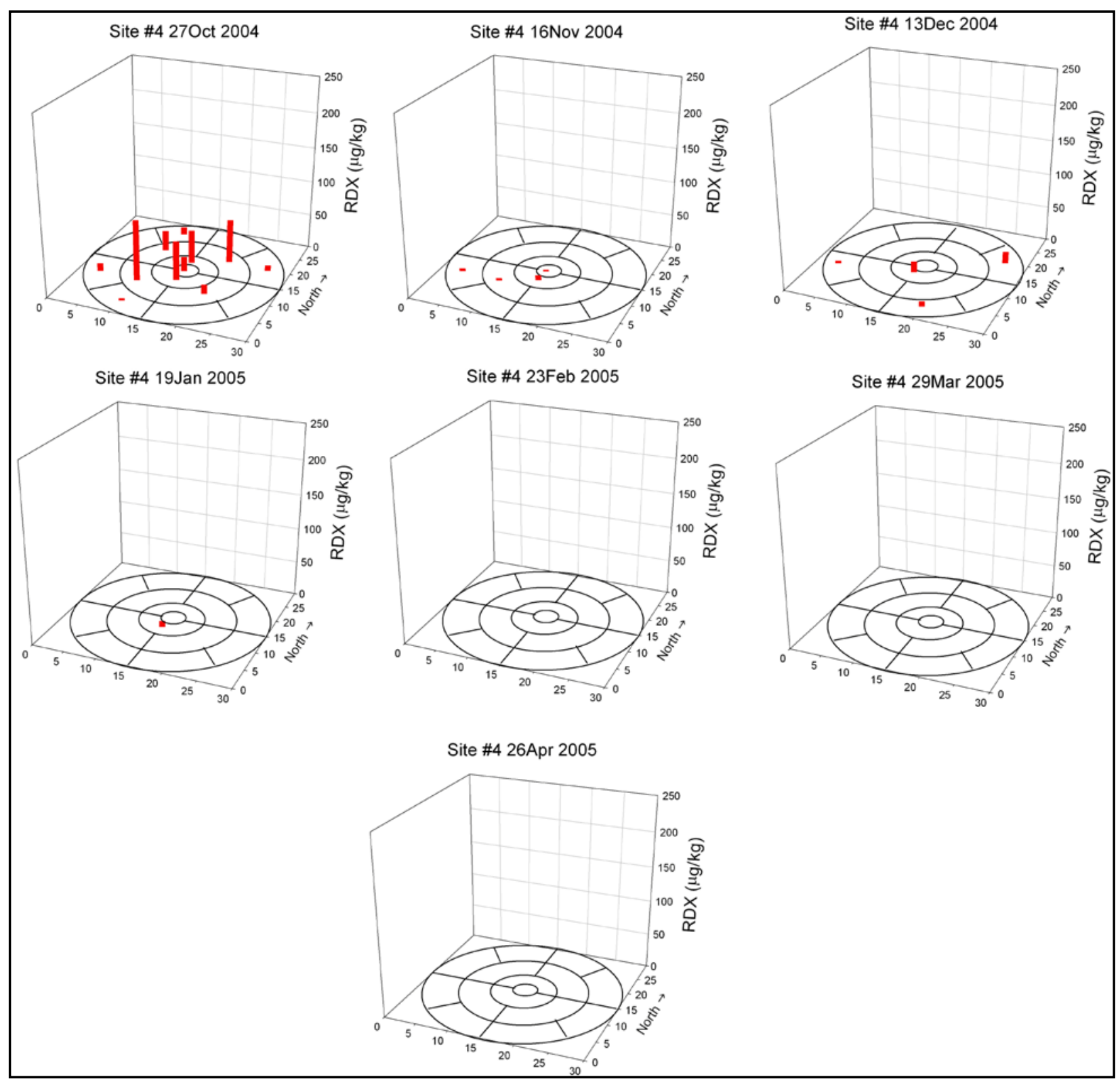

Figure 10. RDX concentrations on site \#4 (treated) during the duration of the study.

The total estimated mass of RDX per site on both the treated and control sites is detailed in Figure 11. At the beginning of the study, control sites contained an estimated $45 \mathrm{mg}$ of RDX per site after BiP operations. Treated sites in the same time frame contained an estimated $25 \mathrm{mg}$ of $\mathrm{RDX}$ per site. After the initial sampling event, the RDX mass decreased on both treated and untreated sites. The most apparent difference between the treated and control sites was at the onset of the study, when half as much estimated RDX mass per site was observed. This is consistent with laboratory observations that the hydroxide- $\mathrm{RDX}$ reaction is relatively 
rapid. Aside from the immediately observed effects of hydroxide addition, further effects could not be quantified.

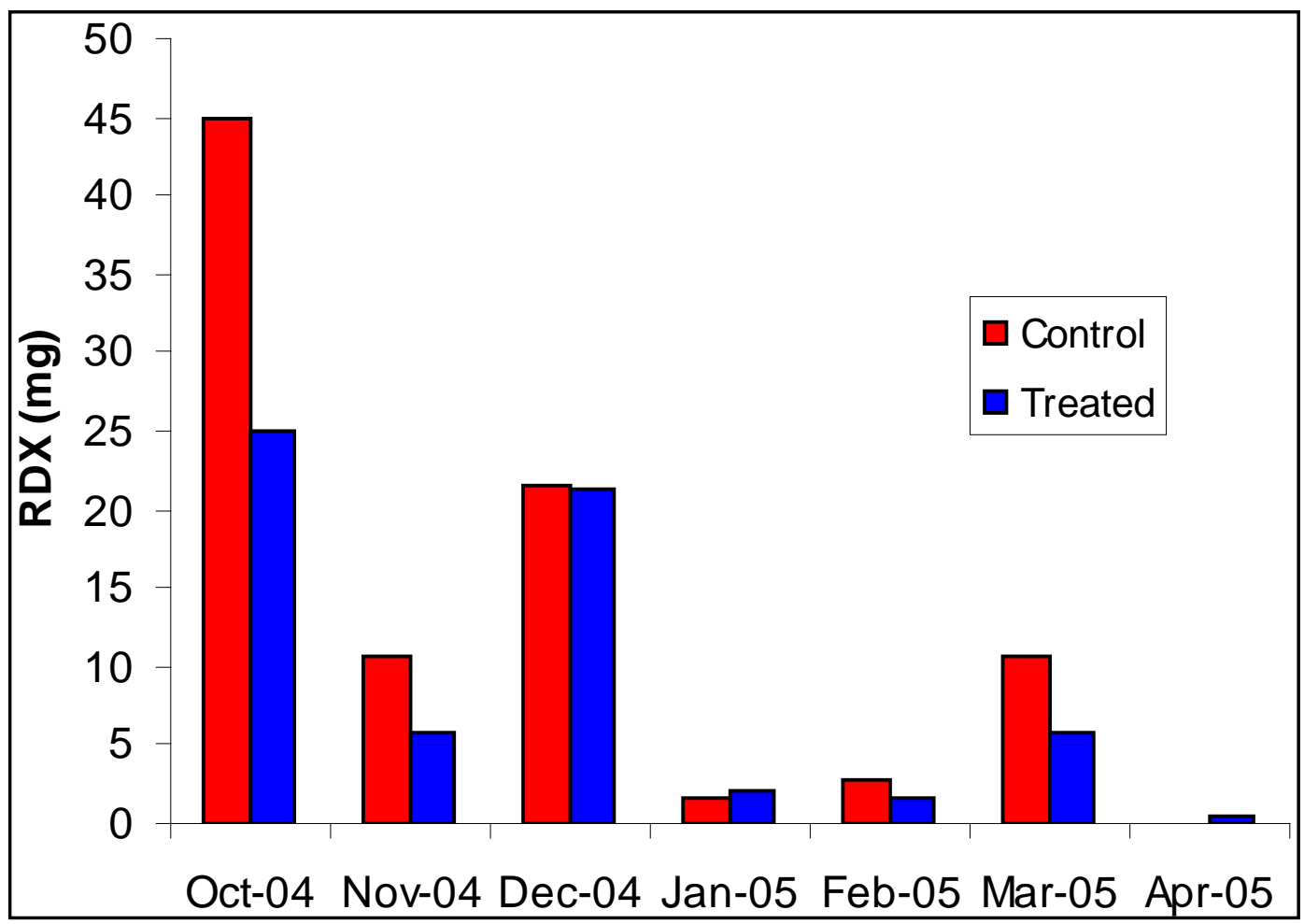

Figure 11. Total estimated mass of RDX per site on treated and control sites over the course of the study.

Comparing RDX concentrations and mass estimates between the treated and untreated sites suggests that the topical addition of hydrated lime had an effect on RDX concentration from day zero. As the study progressed, the difference between RDX concentrations on the treated and untreated sites became less clear. This is consistent with the conclusions of two earlier laboratory studies on lime addition for the treatment of MCs. First, the hydroxide-RDX reaction is relatively rapid (Hansen et al. 2003), so bringing a hydroxide source such as hydrated lime into contact with RDX immediately reduces RDX concentration. Second, soil acts as a significant hydroxide sink, so if the hydrated lime is not applied directly to the deposited RDX, the hydroxide will not transport to the RDX. The difficulty in affecting physical transport of hydroxide has implications for the use of lime application on training ranges. $\mathrm{RDX}$ deposited during training exercises presumably consists of very fine particles $(<50 \mu \mathrm{m})$ (Hewitt et al. 2003). These particles have a relatively slow dissolution rate (Lynch et al. 2003). Sufficient hydrated lime to effect complete destruction of the RDX particle must be brought into direct contact with the particle or the 
application will be less than effective. In this study hydrated lime was applied topically to recently deposited MC particles. The observed RDX concentrations suggest that hydroxide did not reach all of the MC particles on the treated sites. This is a shortcoming of either the application rate or the application method. To improve coverage over the treatment area, a greater application rate could be used to account for challenges in widescale application methods. Other application methods could also be attempted to improve the coverage of lime or provide mixing along with application.

The total estimated mass of TNT per site on both the treated and control sites is detailed in Figure 12. Complete TNT concentration results are given in Appendix A. The mass of TNT detonated during BiP operations was 82 percent less than the mass of RDX detonated. With less TNT available, detection of TNT on both treated and control sites was haphazard, and more areas exhibited non-detect values for TNT. No clear pattern of TNT deposition or disappearance was evident from the sampling data.

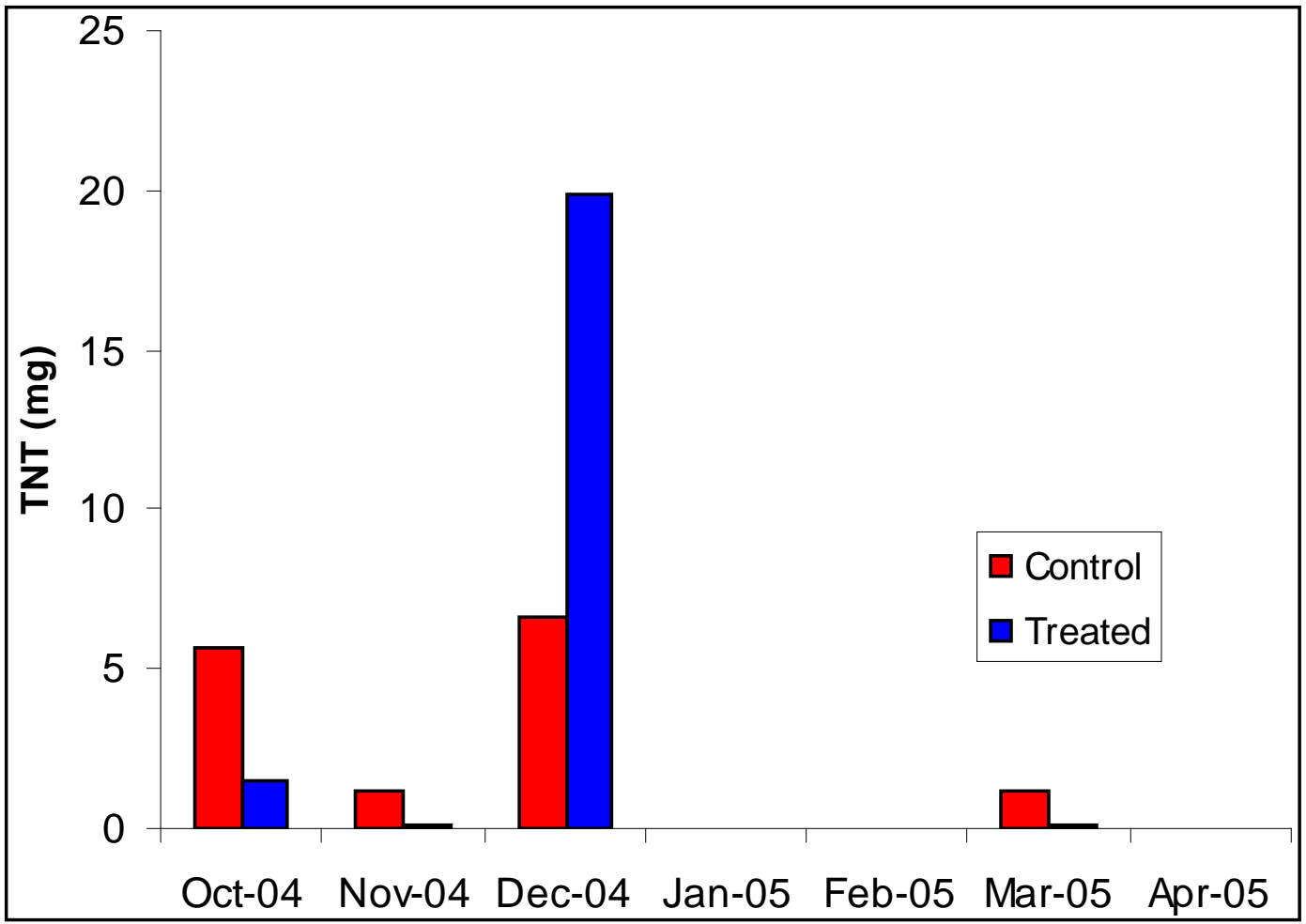

Figure 12. Total estimated mass of TNT per site on treated and control sites over the course of the study. 


\section{Identification of Interfering Compounds}
A broad hump of co-eluting compounds initially prevented the identification of RDX in HPLC analysis. Since the soil samples were collected from the surface, this was assumed to be interference from plant compounds. A cleanup procedure was implemented that had previously been described for analyses of explosives in plant tissue (Larson et al. 1998, 1999). Samples that had not undergone the cleanup procedure were analyzed by LC/ MS to identify the interfering compounds. The major component was determined to be bis(2-ethylhexyl)phthalate, a commercially available plasticizer. 


\section{Conclusions}

The objective of this study was to provide quantitative information regarding the efficacy of on-site treatment of MCs following BiP operations. This study has confirmed some aspects of treating MCs with hydrated lime and outlined some of the challenges associated with developing lime treatment technology for training ranges. Specifically, samples taken immediately following topical application of hydrated lime demonstrate that lime does have an immediate effect on RDX concentration. However, over the course of the study it became apparent that the physical process of hydroxide transport limited the effectiveness of the treatment. MC residues unaffected by lime treatment remained at the end of the study. This is most likely due to poor contact between MC residues and hydrated lime.

This study has highlighted three challenges to consider as technology development moves forward on alkaline treatment of MCs. First, inconsistent RDX concentrations obscured the results of the field study. It will be necessary to account for high concentration variance in future studies, possibly by performing more controlled studies or investigating different sampling strategies. A necessary step is moving to a site where groundwater lysimeters may be placed under the study area, allowing for a thorough mass balance of RDX. Second, the application method will make an important impact on the success of the treatment. Application methods will need to be developed that deliver hydrated lime directly to the MC residues of concern, mitigating the poor transport of hydroxide in the soil environment. This will include investigating the possibility of mixing or tilling in hydrated lime at the time of application. Finally, application rates will need to be tailored to individual applications so that enough alkaline material is delivered to effect complete destruction of the MC residues of concern. Future studies should incorporate higher and lower lime applications as a sensitivity study and seek to delineate $\mathrm{pH}$ profiles at depth to delineate the hydroxide treatment zone. Answering these challenges will develop a technology that helps sustain Army training ranges into the future. 


\section{References}

Brooks, M. C., J . L. Davis, S. L. Larson, D. R. Felt, and C. C. Nestler. 2003. Topical lime treatment for containment of source zone energetics contamination. ERDC/ EL TR-03-19. Vicksburg, MS: U.S. Army Engineer Research and Development Center, Environmental Laboratory.

Borthwick, J . O., and E. A. Beshore. 2000. Sustaining DoD ranges: A national environmental challenge. Federal Facilities Environmental J ournal. Summer: $17-25$.

Clausen, J., J . Robb, D. Curry, and N. Korte. 2004. A case study of contaminants on military training ranges: Camp Edwards Massachusetts, USA. Environmental Pollution 129: 13-21.

Hansen, L. D., S. L. Larson, J . L. Davis, J . M. Cullinane, C. C. Nestler, and D. R. Felt. 2003. Lime treatment of 2,4,6-trinitrotoluene contaminated soils: Proof of concept study. ERDC/ EL TR-03-15. Vicksburg, MS: U.S. Army Engineer Research and Development Center, Environmental Laboratory.

Hewitt, A. D., T. F. J enkins, T. A. Ranney, J . A. Stark, M. E. Walsh, S. Taylor, M. R. Walsh, D. J. Lambert, N. M. Perron, N. H. Collins, and R. Karn. 2003. Estimates for explosives residue from the detonation of Army munitions. ERDC/ CRREL TR-03-16. Hanover, NH: U.S. Army Engineer Research and Development Center, Cold Regions Research and Engineering Laboratory.

Hewitt, A. D., T. F. J enkins, M. E. Walsh, M. R. Walsh, and S. Taylor. 2005. RDX and TNT residues from live-fire and blow-in-place detonations. Chemosphere 61(6): 888-894.

J ankowsky, J. V. 1891. Uber eine reaction der dinitrokoper. Berichte 24: 971.

Larson, S. L., A. B. Strong, S. L. Yost, B. L. Escalon, and D. Parker. 1998. Analysis of explosives in plant tissues: Modifications to method 8330 for soil. Technical Report IRRP-98-5. Vicksburg, MS: U.S. Army Engineer Waterways Experiment Station.

Larson, S. L., R. P. J ones, L. Escalon, and D. Parker. 1999. Classification of explosives transformation products in plant tissue. Environmental Toxicology and Chemistry 18: 1270-1276.

Lynch, J . C., J . M. Brannon, K. Hatfield, and J . J . Delfino. 2003. An exploratory approach to modeling explosive compound persistence and flux using dissolution kinetics. J ournal of Contaminant Hydrology 66: 147-159.

National Oceanic and Atmospheric Administration. 2002. Divisional normals and standard deviations of temperature, precipitation, and heating and cooling degree days 1971-2000. Asheville, NC: National Climatic Data Center. 
Pennington, J . C., T. F. J enkins, G. Ampleman, S. Thiboutot, J . M. Brannon, J . Lewis, J. E. Delaney, J . Clausen, A. D. Hewitt, M. A. Hollander, C. A. Hayes, J . A. Stark, A. Marois, S. Brochu, H. Q. Dinh, D. Lambert, A. Gagnon, M. Bouchard, R. Martel, P. Brousseau, N. M. Perron, R. Lefebvre, W. Davis, T. A. Ranney, C. Gauthier, S. Taylor, and J. M. Ballard 2003. Distribution and fate of energetics on DoD test and training ranges: Report 3. ERDC/ EL TR-03-2. Vicksburg, MS: U.S. Army Engineer Research and Development Center, Environmental Laboratory.

U.S. Army. 2004. The Army Strategy for the Environment. Washington, DC: Office of the Assisstant Secretary of the Army for Installations and Environment.

U.S. Department of Agriculture, Natural Resources Conservation Service. 1958. Soil survey of Madison County, Alabama. Series 1947, No 3. Washington, DC.

U.S. Environmental Protection Agency. 1994a. Test methods for evaluating solid waste, method \# 8330, nitroaromatics and nitramines by high performance liquid chromatography. SW 846. Washington, DC.

U.S. Environmental Protection Agency. 1994b. Test methods for evaluating solid waste, method \# 8091, nitroaromatics and cyclic ketones by gas chromatography. SW 846. Washington, DC.

Urbanski, T. 1964. Chemistry and technology of explosives. New York: McMillan.

Walsh, M. R. 2004. Field sampling tools for explosives residues developed at CRREL. ERDC/CRREL TN-04-1. Hanover, NH: U.S. Army Engineer Research and Development Center, Cold Regions Research and Engineering Laboratory. 


\section{Appendix A}

\section{Site Soil Conditions}

Table A1. Test plot soil constituent analysis.

\begin{tabular}{|l|l|}
\hline Soil Constituent & Concentration \\
\hline $\mathrm{Ca}$ & $1,960 \mathrm{mg} / \mathrm{kg}$ \\
\hline $\mathrm{Fe}$ & $32,800 \mathrm{mg} / \mathrm{kg}$ \\
\hline $\mathrm{Mg}$ & $1,040 \mathrm{mg} / \mathrm{kg}$ \\
\hline $\mathrm{K}$ & $1,190 \mathrm{mg} / \mathrm{kg}$ \\
\hline $\mathrm{Na}$ & $46 \mathrm{mg} / \mathrm{kg}$ \\
\hline $\mathrm{TKN}$ & $332 \mathrm{mg} / \mathrm{kg}$ \\
\hline $\mathrm{TP}$ & $<50 \mathrm{mg} / \mathrm{kg}$ \\
\hline $\mathrm{OPO}_{4}$ & $<1.0 \mathrm{mg} / \mathrm{kg}$ \\
\hline $\mathrm{NH}_{3}-\mathrm{N}$ & $11 \mathrm{mg} / \mathrm{kg}$ \\
\hline $\mathrm{NO}_{2} / \mathrm{NO}_{3}$ & $<10 \mathrm{mg} / \mathrm{kg}$ \\
\hline $\mathrm{SO}_{4}$ & $10 \mathrm{mg} / \mathrm{kg}$ \\
\hline $\mathrm{CL}$ & $<10 \mathrm{mg} / \mathrm{kg}$ \\
\hline Cation exchange capacity & 18.7 \\
\hline Total organic carbon & $1.49 \mathrm{percent}$ \\
\hline
\end{tabular}




\section{pH}

Table A2. pH at the soil surface on site \#1 (control) by sampling area.

\begin{tabular}{|c|c|c|c|c|c|c|c|}
\hline \multirow[b]{2}{*}{ Sample Area } & \multicolumn{6}{|c|}{ Site \#1 } & \multirow[b]{2}{*}{ 27-Apr-05 } \\
\hline & 28-Oct-04 & 17-Nov-04 & 13-Dec-04 & 19-Jan-05 & 23-Feb-05 & 29-Mar-05 & \\
\hline 1 & 5.21 & 5.36 & 5.37 & 5.17 & 5.57 & 5.59 & 5.56 \\
\hline 2 & 5.39 & 5.54 & 5.58 & 5.61 & 5.33 & 6.06 & 6.08 \\
\hline 3 & 5.26 & 5.45 & 5.59 & 5.20 & 5.29 & 5.68 & 6.07 \\
\hline 4 & 5.67 & 6.30 & 5.82 & 5.80 & 5.75 & 6.27 & 6.46 \\
\hline 5 & 5.94 & 5.57 & 5.80 & 5.75 & 6.21 & 6.20 & 6.30 \\
\hline 6 & 5.73 & 5.67 & 5.57 & 5.53 & 5.43 & 5.93 & 6.22 \\
\hline 7 & 5.68 & 5.71 & 5.82 & 5.33 & 5.64 & 5.87 & 6.10 \\
\hline 8 & 6.07 & 6.15 & 5.87 & 5.50 & 5.89 & 6.04 & 6.07 \\
\hline 9 & 5.58 & 6.01 & 5.75 & 5.46 & 6.05 & 6.22 & 6.36 \\
\hline 10 & 5.49 & 5.72 & 5.65 & 5.73 & 5.96 & 5.91 & 6.26 \\
\hline 11 & 5.53 & 5.58 & 5.63 & 0.00 & 5.65 & 5.79 & 5.95 \\
\hline 12 & 5.47 & 5.68 & 5.83 & 5.43 & 5.79 & 6.06 & 6.46 \\
\hline 13 & 5.53 & 5.44 & 5.47 & 0.00 & 5.53 & 5.80 & 6.17 \\
\hline 14 & 5.49 & 5.68 & 5.75 & 5.59 & 5.66 & 6.03 & 6.32 \\
\hline 15 & 5.57 & 5.56 & 5.62 & 0.00 & 5.73 & 6.24 & 6.32 \\
\hline
\end{tabular}

Table A3. pH at the soil surface on site \#2 (control) by sampling area.

\begin{tabular}{|c|c|c|c|c|c|c|c|}
\hline \multirow[b]{2}{*}{ Sample Area } & \multicolumn{6}{|c|}{ Site \#2 } & \multirow[b]{2}{*}{ 27-Apr-05 } \\
\hline & 28-Oct-04 & 17-Nov-04 & 13-Dec-04 & 19-Jan-05 & 23-Feb-05 & 29-Mar-05 & \\
\hline 1 & & 5.87 & 5.90 & 5.65 & 5.56 & 5.71 & \\
\hline 2 & & 5.89 & 6.04 & 5.97 & 5.64 & 6.06 & \\
\hline 3 & & 6.17 & 6.09 & 5.70 & 5.52 & 5.87 & \\
\hline 4 & & 6.08 & 6.37 & 5.97 & 5.78 & 6.22 & \\
\hline 5 & & 5.72 & 6.03 & 5.89 & 5.71 & 6.05 & \\
\hline 6 & ర్d & 6.19 & 5.92 & 5.64 & 6.21 & 6.10 & ర \\
\hline 7 & $\frac{0}{ㅇ}$ & 5.99 & 5.95 & 5.63 & 5.87 & 6.24 & $\frac{0}{0}$ \\
\hline 8 & ह్ర & 5.80 & 6.07 & 5.78 & 5.85 & 6.31 & ह్ర \\
\hline 9 & $\omega$ & 5.84 & 6.08 & 5.84 & 5.81 & 6.11 & ஸे \\
\hline 10 & 之 & 5.97 & 6.17 & 5.91 & 5.92 & 6.25 & i \\
\hline 11 & & 6.05 & 6.48 & 5.79 & 5.64 & 6.31 & \\
\hline 12 & & 5.85 & 5.84 & 5.72 & 6.24 & 6.45 & \\
\hline 13 & & 6.78 & 5.94 & 5.71 & 6.26 & 6.15 & \\
\hline 14 & & 6.44 & 6.12 & 5.81 & 5.99 & 6.29 & \\
\hline 15 & & 5.83 & 6.28 & 6.24 & 6.66 & 6.68 & \\
\hline
\end{tabular}


Table A4. pH at the soil surface on site \#3 (control) by sampling area.

\begin{tabular}{|c|c|c|c|c|c|c|c|}
\hline \multicolumn{8}{|c|}{$\begin{array}{l}\text { Site \#3 } \\
\text { pH of top } 1 \text { inch }\end{array}$} \\
\hline Sample Area & 28-Oct-04 & 17-Nov-04 & 13-Dec-04 & 19-Jan-05 & 23-Feb-05 & 29-Mar-05 & 27-Apr-05 \\
\hline 1 & \multirow{15}{*}{ 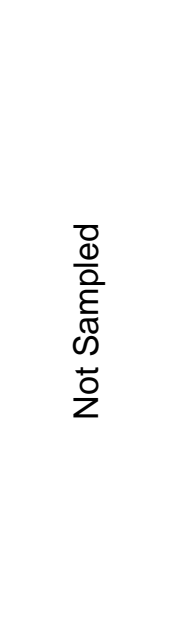 } & 5.69 & 5.82 & 5.66 & 5.30 & 5.70 & \multirow{15}{*}{$\begin{array}{l}\bar{d} \\
\frac{d}{0} \\
\frac{0}{E} \\
\tilde{\omega} \\
\stackrel{0}{0} \\
\frac{0}{z}\end{array}$} \\
\hline 2 & & 5.92 & 5.84 & 5.58 & 5.86 & 5.99 & \\
\hline 3 & & 6.03 & 5.83 & 5.66 & 5.35 & 5.87 & \\
\hline 4 & & 5.89 & 5.81 & 5.76 & 5.77 & 6.18 & \\
\hline 5 & & 5.64 & 5.92 & 5.76 & 6.04 & 6.51 & \\
\hline 6 & & 6.04 & 6.04 & 5.92 & 6.21 & 5.81 & \\
\hline 7 & & 5.75 & 5.57 & 5.72 & 5.89 & 6.02 & \\
\hline 8 & & 6.02 & 6.00 & 5.74 & 5.78 & 6.41 & \\
\hline 9 & & 5.72 & 5.82 & 5.83 & 6.07 & 6.00 & \\
\hline 10 & & 5.95 & 5.84 & 5.87 & 5.72 & 6.12 & \\
\hline 11 & & 5.97 & 5.98 & 5.80 & 6.82 & 6.45 & \\
\hline 12 & & 5.93 & 5.87 & 5.83 & 6.18 & 6.11 & \\
\hline 13 & & 6.23 & 5.96 & 5.87 & 5.87 & 6.21 & \\
\hline 14 & & 5.79 & 5.69 & 5.47 & 5.88 & 5.80 & \\
\hline 15 & & 5.68 & 5.64 & 5.57 & 5.71 & 5.72 & \\
\hline
\end{tabular}

Table A5. pH at the soil surface on site \#4 (treated) by sampling area.

\begin{tabular}{|c|c|c|c|c|c|c|c|}
\hline & & & Site & & & & \\
\hline & & & & of top 1 in & & & \\
\hline Sample Area & 28-Oct-04 & 17-Nov-04 & 13-Dec-04 & 19-Jan-05 & 23-Feb-05 & 29-Mar-05 & 27-Apr-05 \\
\hline 1 & 11.15 & 7.85 & 7.63 & 7.77 & 7.39 & 8.19 & 7.89 \\
\hline 2 & 7.55 & 7.69 & 7.33 & 7.54 & 8.03 & 8.12 & 7.93 \\
\hline 3 & 7.29 & 7.60 & 7.43 & 7.58 & 8.06 & 8.07 & 7.87 \\
\hline 4 & 8.01 & 7.63 & 7.46 & 7.75 & 8.08 & 8.13 & 7.79 \\
\hline 5 & 7.82 & 7.38 & 7.39 & 7.58 & 8.08 & 8.00 & 7.88 \\
\hline 6 & 8.21 & 7.67 & 7.40 & 7.72 & 7.99 & 8.08 & 7.87 \\
\hline 7 & 8.00 & 7.62 & 7.46 & 7.58 & 7.53 & 8.10 & 7.73 \\
\hline 8 & 7.67 & 7.51 & 7.46 & 7.58 & 8.08 & 8.07 & 7.83 \\
\hline 9 & 7.93 & 7.40 & 7.43 & 7.49 & 7.99 & 7.92 & 7.94 \\
\hline 10 & 7.71 & 7.44 & 7.56 & 7.34 & 7.96 & 7.95 & 7.60 \\
\hline 11 & 7.70 & 7.31 & 7.28 & 7.37 & 7.91 & 7.84 & 7.70 \\
\hline 12 & 7.89 & 7.43 & 7.61 & 7.40 & 7.93 & 8.05 & 7.91 \\
\hline 13 & 7.53 & 7.51 & 7.51 & 7.45 & 8.00 & 8.01 & 7.96 \\
\hline 14 & 7.38 & 7.54 & 7.55 & 7.63 & 7.94 & 7.98 & 7.57 \\
\hline 15 & 9.02 & 7.53 & 7.78 & 7.74 & 7.99 & 7.85 & 7.95 \\
\hline
\end{tabular}


Table A6. pH at the soil surface on site \#5 (treated) by sampling area.

\begin{tabular}{|cccccccc|}
\hline & \multicolumn{7}{c|}{ Site \#5 } \\
pH of top 1 inch \\
Sample Area & 28-Oct-04 & 17-Nov-04 & 13-Dec-04 & 19-Jan-05 & 23-Feb-05 & 29-Mar-05 & 27-Apr-05 \\
1 & 9.78 & 7.41 & 7.59 & 7.95 & 7.92 & 7.93 & 7.73 \\
2 & 7.56 & 6.99 & 7.43 & 7.68 & 7.92 & 7.76 & 7.67 \\
3 & 7.63 & 7.17 & 7.29 & 7.89 & 7.84 & 7.94 & 7.70 \\
4 & 7.55 & 7.28 & 7.47 & 7.82 & 7.86 & 8.05 & 7.81 \\
5 & 7.41 & 7.36 & 7.40 & 7.72 & 7.79 & 7.91 & 7.64 \\
6 & 7.37 & 7.35 & 7.46 & 7.63 & 7.86 & 7.66 & 7.53 \\
7 & 7.49 & 7.50 & 7.29 & 7.59 & 7.91 & 7.78 & 7.48 \\
8 & 7.78 & 7.44 & 7.47 & 7.64 & 7.73 & 7.58 & 7.74 \\
9 & 7.13 & 7.21 & 7.45 & 7.55 & 7.74 & 7.63 & 7.59 \\
10 & 7.51 & 7.37 & 7.31 & 7.44 & 7.77 & 7.58 & 7.68 \\
11 & 7.47 & 7.15 & 7.30 & 7.69 & 7.77 & 7.98 & 7.55 \\
12 & 7.61 & 7.32 & 7.50 & 7.24 & 7.74 & 7.48 & 7.73 \\
13 & 7.45 & 7.12 & 7.46 & 7.41 & 7.83 & 7.98 & 7.59 \\
14 & 7.20 & 7.16 & 7.36 & 7.30 & 7.55 & 7.57 & 7.74 \\
15 & 7.82 & 7.17 & 7.50 & 7.35 & 7.92 & 7.69 & 7.45 \\
\hline
\end{tabular}

Table A7. pH at the soil surface on site \#6 (treated) by sampling area.

\begin{tabular}{|cccccccc|}
\hline & \multicolumn{7}{c|}{ Site \#6 } \\
pH of top 1 inch \\
Sample Area & 28-Oct-04 & 17-Nov-04 & 13-Dec-04 & 19-Jan-05 & 23-Feb-05 & 29-Mar-05 & 27-Apr-05 \\
1 & n/a & 7.50 & 10.09 & 7.79 & 8.14 & 7.98 & 7.87 \\
2 & n/a & 7.59 & 7.71 & 7.86 & 7.84 & 7.84 & 7.74 \\
3 & n/a & 7.57 & 7.70 & 7.56 & 7.92 & 8.09 & 7.90 \\
4 & n/a & 7.40 & 7.59 & 7.73 & 8.04 & 7.88 & 7.56 \\
5 & n/a & 7.44 & 7.73 & 7.69 & 7.72 & 7.83 & 7.57 \\
6 & n/a & 7.50 & 7.63 & 7.76 & 7.97 & 7.77 & 7.64 \\
7 & $\mathrm{n} / \mathrm{a}$ & 7.49 & 7.62 & 7.70 & 7.94 & 7.80 & 7.70 \\
8 & 7.69 & 7.40 & 7.35 & 7.55 & 7.80 & 7.91 & 7.63 \\
9 & 7.42 & 7.45 & 7.39 & 7.71 & 7.83 & 7.73 & 7.69 \\
10 & 7.24 & 7.32 & 7.33 & 7.69 & 7.75 & 7.74 & 7.38 \\
11 & $\mathrm{n} / \mathrm{a}$ & 7.45 & 7.38 & 7.67 & 8.03 & 7.78 & 7.61 \\
12 & $\mathrm{n} / \mathrm{a}$ & 7.37 & 7.25 & 7.91 & 7.94 & 7.63 & 7.38 \\
13 & 7.30 & 7.36 & 7.50 & 7.70 & 7.75 & 7.36 & 7.49 \\
14 & 7.35 & 7.31 & 7.35 & 7.74 & 7.79 & 7.70 & 7.33 \\
15 & 7.39 & 7.36 & 7.42 & 7.65 & 8.03 & 7.78 & 7.54 \\
\hline
\end{tabular}




\section{RDX Concentrations}

Table A8. RDX concentrations at the soil surface on site \#1 (control) by sampling area.

\begin{tabular}{|cccccccc|}
\hline & \multicolumn{7}{c|}{ Site \#1 } \\
Sample Area & $\mathbf{2 8 - O c t - 0 4}$ & 17-Nov-04 & 13-Dec-04 & 19-Jan-05 & 23-Feb-05 & 29-Mar-05 & 27-Apr-05 \\
1 & 52.20 & 15.56 & $<2.0$ & $<2.0$ & $<2.0$ & $<2.0$ & $<2.0$ \\
2 & 116.36 & 37.00 & 15.88 & $<2.0$ & 10.98 & 7.58 & $<2.0$ \\
3 & 27.93 & 4.49 & 222.00 & 2.40 & 2.44 & 6.94 & $<2.0$ \\
4 & $<2.0$ & $<2.0$ & 6.58 & $<2.0$ & $<2.0$ & $<2.0$ & $<2.0$ \\
5 & 41.67 & 27.00 & 5.48 & $<2.0$ & 4.38 & 11.08 & $<2.0$ \\
6 & 25.02 & $<2.0$ & 6.10 & $<2.0$ & $<2.0$ & $<2.0$ & $<2.0$ \\
7 & 6.02 & $<2.0$ & $<2.0$ & $<2.0$ & 6.58 & $<2.0$ & $<2.0$ \\
8 & 7.35 & $<2.0$ & $<2.0$ & $<2.0$ & $<2.0$ & $<2.0$ & $<2.0$ \\
9 & $<2.0$ & $<2.0$ & $<2.0$ & $<2.0$ & $<2.0$ & $<2.0$ & $<2.0$ \\
10 & $<2.0$ & $<2.0$ & $<2.0$ & $<2.0$ & $<2.0$ & $<2.0$ & $<2.0$ \\
11 & 5.82 & $<2.0$ & 3.02 & $<2.0$ & $<2.0$ & $<2.0$ & $<2.0$ \\
12 & 4.37 & $<2.0$ & $<2.0$ & $<2.0$ & $<2.0$ & $<2.0$ & $<2.0$ \\
13 & $<2.0$ & $<2.0$ & $<2.0$ & $<2.0$ & $<2.0$ & $<2.0$ & $<2.0$ \\
14 & 2.09 & $<2.0$ & $<2.0$ & $<2.0$ & $<2.0$ & $<2.0$ & $<2.0$ \\
15 & $<2.0$ & $<2.0$ & $<2.0$ & $<2.0$ & $<2.0$ & $<2.0$ & $<2.0$ \\
\hline
\end{tabular}

Table A9. RDX concentrations at the soil surface on site \#2 (control) by sampling area.

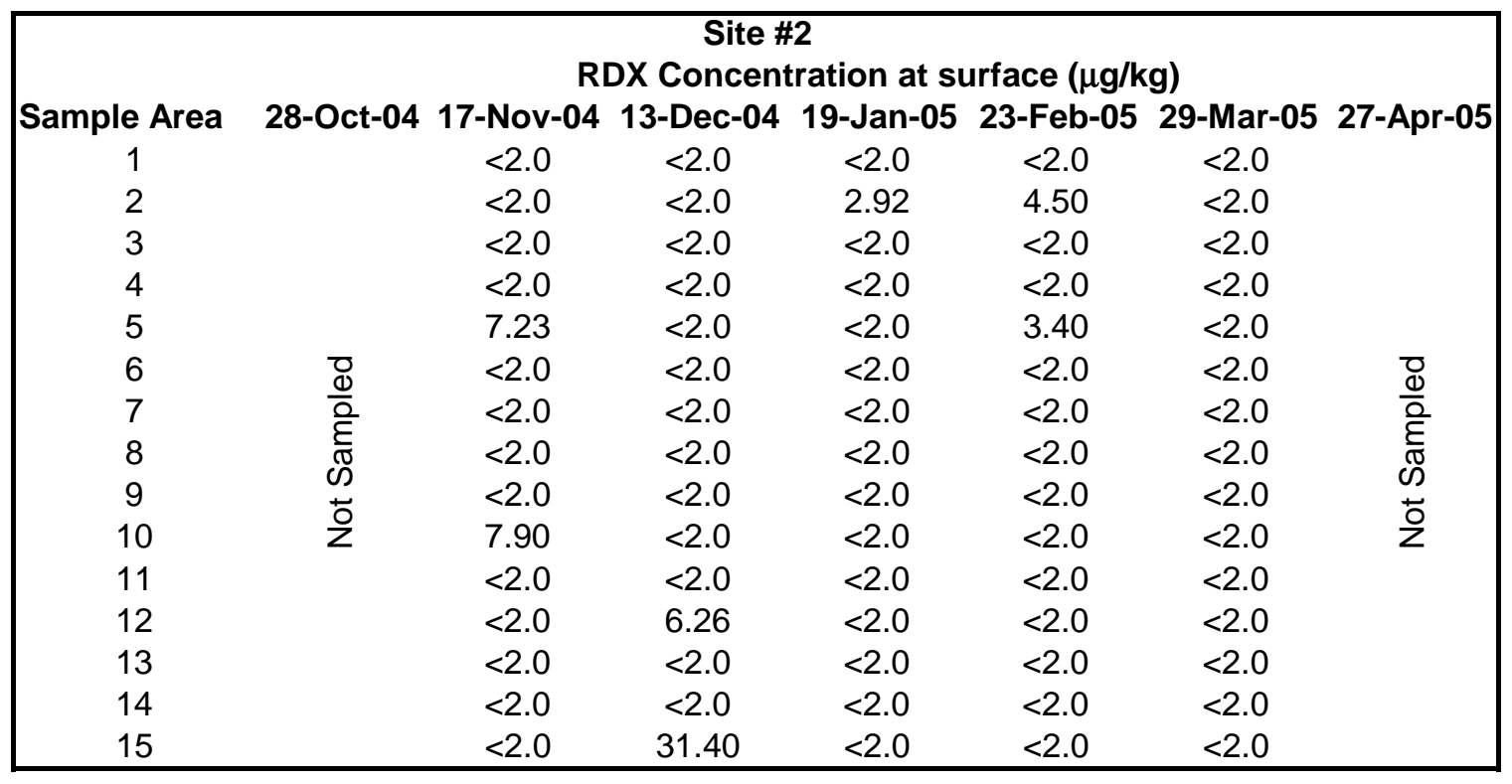


Table A10. RDX concentrations at the soil surface on site \#3 (control) by sampling area.

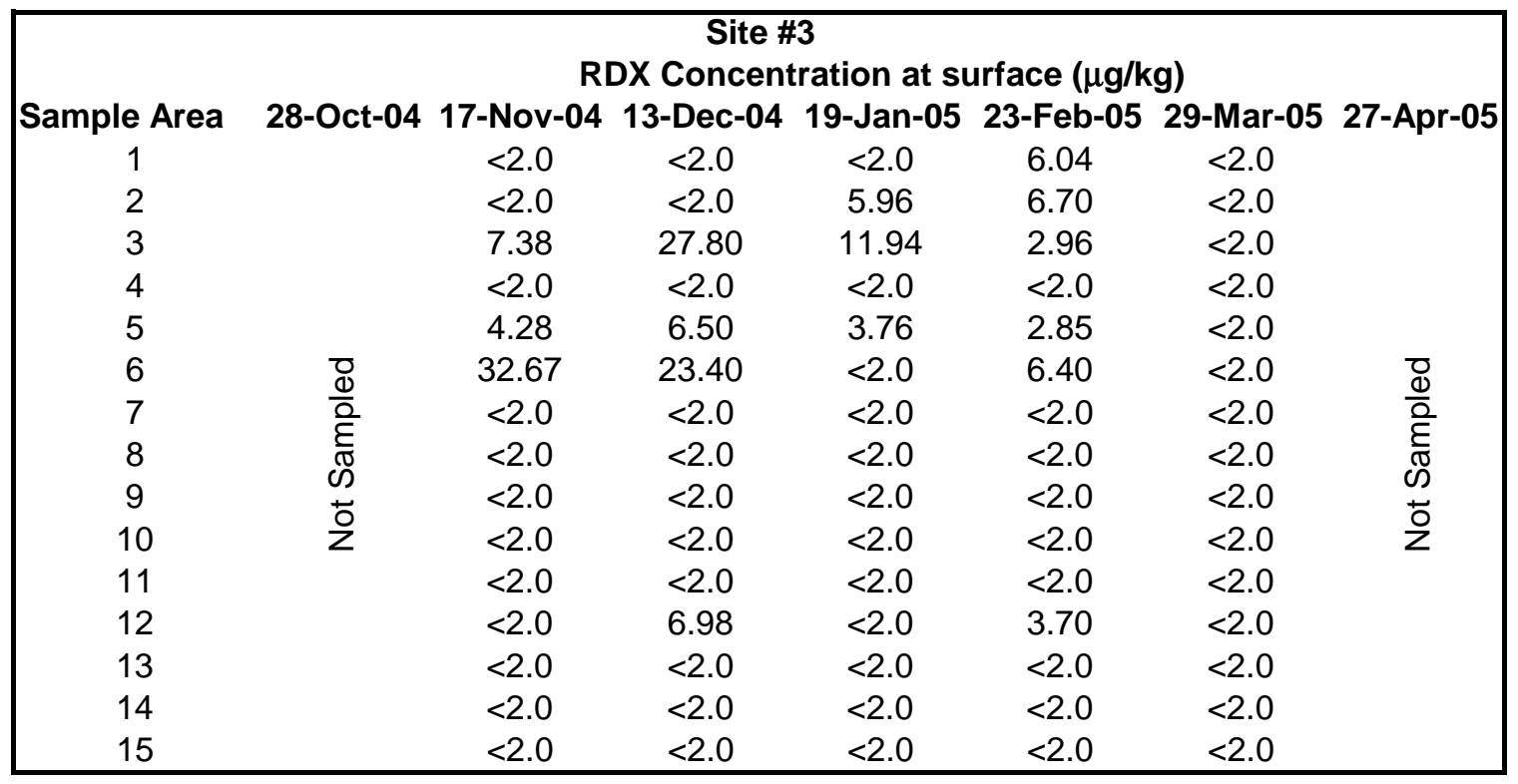

Table A11. RDX concentrations at the soil surface on site \#4 (treated) by sampling area.

\begin{tabular}{|cccccccc|}
\hline & \multicolumn{7}{c|}{ Site \#4 } \\
Sample Area & 28-Oct-04 & 17-Nov-04 & 13-Dec-04 & 19-Jan-05 & 23-Feb-05 & 29-Mar-05 & 27-Apr-05 \\
1 & 21.40 & 2.44 & $<2.0$ & $<2.0$ & $<2.0$ & $<2.0$ & $<2.0$ \\
2 & 18.25 & $<2.0$ & $<2.0$ & $<2.0$ & $<2.0$ & $<2.0$ & $<2.0$ \\
3 & 13.03 & 7.72 & 16.66 & 4.97 & $<2.0$ & $<2.0$ & $<2.0$ \\
4 & 13.77 & $<2.0$ & $<2.0$ & $<2.0$ & $<2.0$ & $<2.0$ & $<2.0$ \\
5 & 14.97 & $<2.0$ & $<2.0$ & $<2.0$ & $<2.0$ & $<2.0$ & $<2.0$ \\
6 & 41.31 & 3.82 & $<2.0$ & $<2.0$ & $<2.0$ & $<2.0$ & $<2.0$ \\
7 & 6.32 & $<2.0$ & $<2.0$ & $<2.0$ & $<2.0$ & $<2.0$ & $<2.0$ \\
8 & 8.32 & $<2.0$ & 17.58 & $<2.0$ & $<2.0$ & $<2.0$ & $<2.0$ \\
9 & $<2.0$ & $<2.0$ & $<2.0$ & $<2.0$ & $<2.0$ & $<2.0$ & $<2.0$ \\
10 & 10.05 & $<2.0$ & $<2.0$ & $<2.0$ & $<2.0$ & $<2.0$ & $<2.0$ \\
11 & 4.22 & $<2.0$ & $<2.0$ & $<2.0$ & $<2.0$ & $<2.0$ & $<2.0$ \\
12 & 10.97 & 4.34 & 4.08 & $<2.0$ & $<2.0$ & $<2.0$ & $<2.0$ \\
13 & 2.75 & $<2.0$ & $<2.0$ & $<2.0$ & $<2.0$ & $<2.0$ & $<2.0$ \\
14 & $<2.0$ & $<2.0$ & 7.28 & $<2.0$ & $<2.0$ & $<2.0$ & $<2.0$ \\
15 & $<2.0$ & $<2.0$ & $<2.0$ & $<2.0$ & $<2.0$ & $<2.0$ & $<2.0$ \\
\hline
\end{tabular}


Table A12. RDX concentrations at the soil surface on site \#5 (treated) by sampling area.

\begin{tabular}{|cccccccc|}
\hline & \multicolumn{7}{c|}{ Site \#5 } \\
Sample Area & 28-Oct-04 & 17-Nov-04 & 13-Dec-04 & 19-Jan-05 & 23-Feb-05) & 29-Mar-05 & 27-Apr-05 \\
1 & 16.90 & $<2.0$ & $<2.0$ & $<2.0$ & $<2.0$ & $<2.0$ & $<2.0$ \\
2 & $<2.0$ & 11.78 & 5.68 & $<2.0$ & $<2.0$ & $<2.0$ & $<2.0$ \\
3 & 7.14 & 51.00 & $<2.0$ & $<2.0$ & 39.00 & $<2.0$ & $<2.0$ \\
4 & $<2.0$ & $<2.0$ & $<2.0$ & $<2.0$ & $<2.0$ & $<2.0$ & $<2.0$ \\
5 & 11.83 & $<2.0$ & $<2.0$ & $<2.0$ & $<2.0$ & $<2.0$ & $<2.0$ \\
6 & 40.59 & $<2.0$ & 4.42 & $<2.0$ & $<2.0$ & $<2.0$ & 5.14 \\
7 & 6.02 & $<2.0$ & $<2.0$ & $<2.0$ & $<2.0$ & $<2.0$ & $<2.0$ \\
8 & 3.44 & $<2.0$ & $<2.0$ & $<2.0$ & $<2.0$ & $<2.0$ & $<2.0$ \\
9 & 4.29 & 2.39 & 32.80 & $<2.0$ & $<2.0$ & $<2.0$ & $<2.0$ \\
10 & 3.27 & $<2.0$ & $<2.0$ & $<2.0$ & $<2.0$ & $<2.0$ & $<2.0$ \\
11 & $<2.0$ & $<2.0$ & $<2.0$ & $<2.0$ & $<2.0$ & $<2.0$ & $<2.0$ \\
12 & 10.04 & $<2.0$ & $<2.0$ & $<2.0$ & $<2.0$ & $<2.0$ & $<2.0$ \\
13 & $<2.0$ & $<2.0$ & 4.02 & $<2.0$ & $<2.0$ & $<2.0$ & $<2.0$ \\
14 & $<2.0$ & $<2.0$ & $<2.0$ & $<2.0$ & $<2.0$ & $<2.0$ & $<2.0$ \\
15 & 2.39 & $<2.0$ & $<2.0$ & $<2.0$ & $<2.0$ & $<2.0$ & $<2.0$ \\
\hline
\end{tabular}

Table A13. RDX concentrations at the soil surface on site \#6 (treated) by sampling area.

\begin{tabular}{|cccccccc|}
\hline \multicolumn{7}{c|}{ RDX Concentration at surface $(\mu \mathrm{g} / \mathrm{kg})$} \\
Sample Area & 28-Oct-04 & 17-Nov-04 & 13-Dec-04 & 19-Jan-05 & 23-Feb-05 & 29-Mar-05 & 27-Apr-05 \\
1 & \#N/A & $<2.0$ & $<2.0$ & $<2.0$ & $<2.0$ & $<2.0$ & $<2.0$ \\
2 & \#N/A & $<2.0$ & 21.20 & 14.78 & $<2.0$ & 5.02 & $<2.0$ \\
3 & \#N/A & 3.86 & $<2.0$ & $<2.0$ & $<2.0$ & 2.10 & $<2.0$ \\
4 & \#N/A & $<2.0$ & $<2.0$ & $<2.0$ & $<2.0$ & $<2.0$ & $<2.0$ \\
5 & \#N/A & $<2.0$ & $<2.0$ & $<2.0$ & $<2.0$ & $<2.0$ & $<2.0$ \\
6 & \#N/A & 2.92 & 12.32 & 15.06 & $<2.0$ & $<2.0$ & $<2.0$ \\
7 & \#N/A & $<2.0$ & $<2.0$ & $<2.0$ & $<2.0$ & $<2.0$ & $<2.0$ \\
8 & $<2.0$ & $<2.0$ & $<2.0$ & $<2.0$ & $<2.0$ & $<2.0$ & $<2.0$ \\
9 & $<2.0$ & $<2.0$ & $<2.0$ & $<2.0$ & $<2.0$ & $<2.0$ & $<2.0$ \\
10 & $<2.0$ & 5.26 & 10.74 & $<2.0$ & $<2.0$ & $<2.0$ & $<2.0$ \\
11 & \#N/A & $<2.0$ & $<2.0$ & $<2.0$ & $<2.0$ & $<2.0$ & $<2.0$ \\
12 & \#N/A & $<2.0$ & $<2.0$ & $<2.0$ & $<2.0$ & 10.86 & $<2.0$ \\
13 & 2.22 & $<2.0$ & $<2.0$ & $<2.0$ & $<2.0$ & $<2.0$ & $<2.0$ \\
14 & $<2.0$ & $<2.0$ & $<2.0$ & $<2.0$ & $<2.0$ & $<2.0$ & $<2.0$ \\
15 & 4.40 & $<2.0$ & 145.00 & $<2.0$ & $<2.0$ & $<2.0$ & $<2.0$ \\
\hline
\end{tabular}




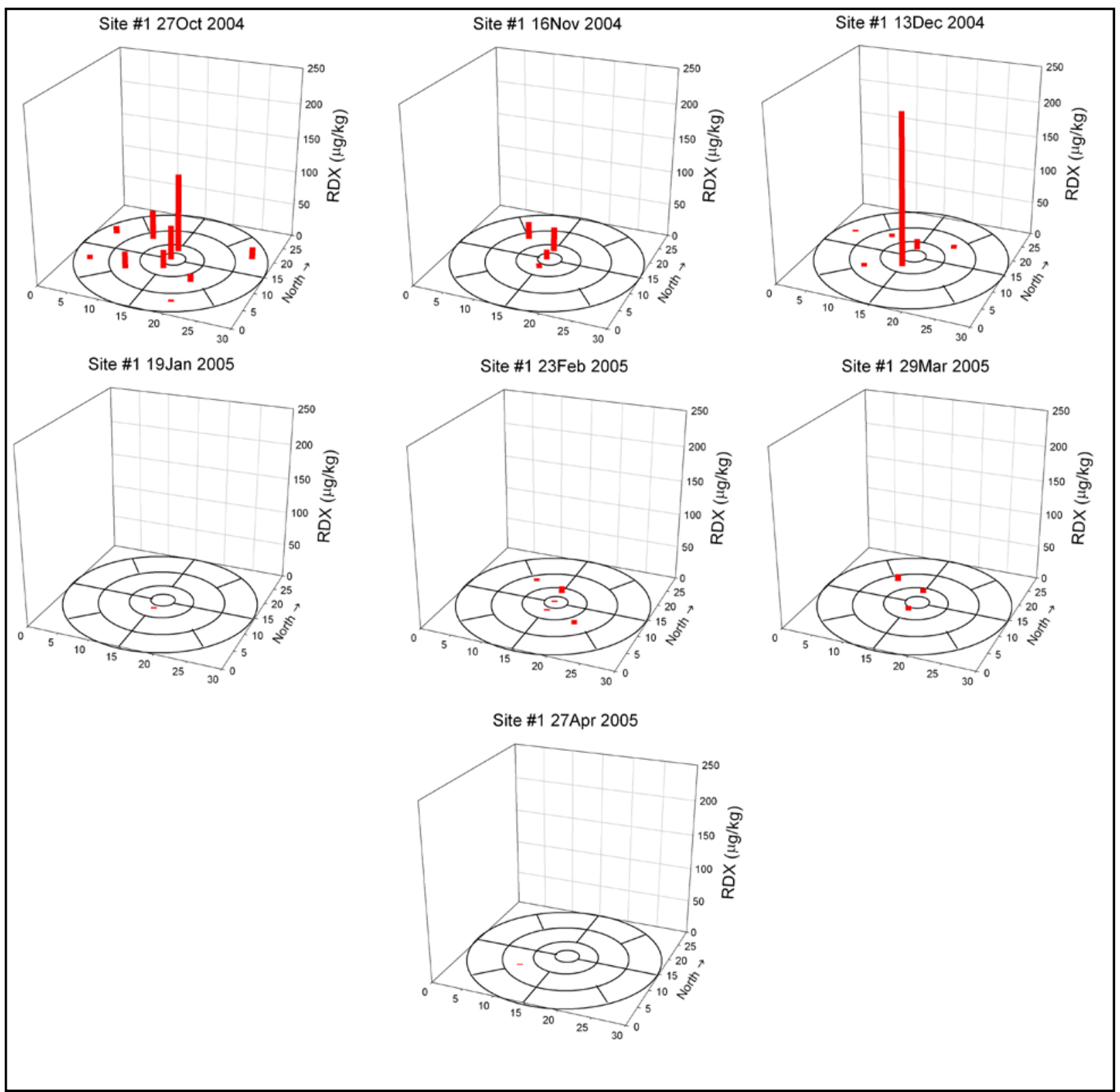

Figure A1. RDX concentrations at the soil surface on site \#1 (control). 


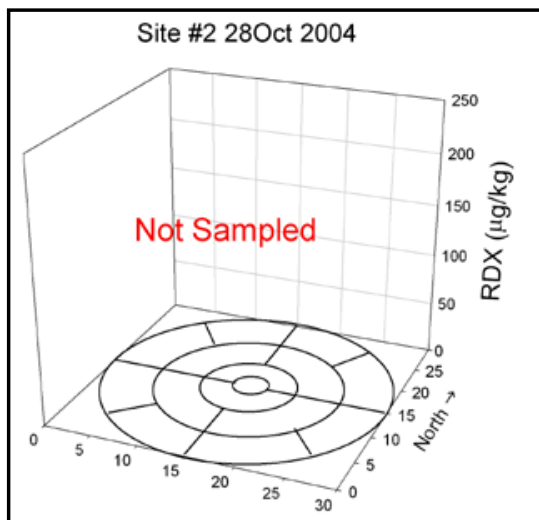

Site \#2 19Jan 2005

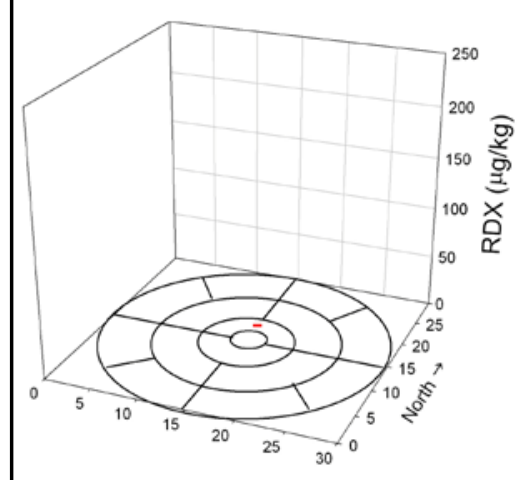

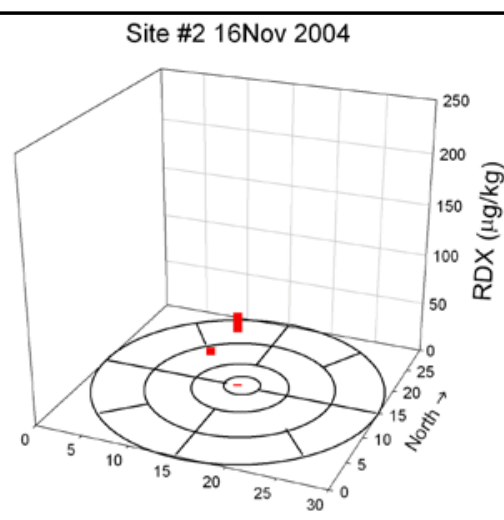

Site \#2 23Feb 2005

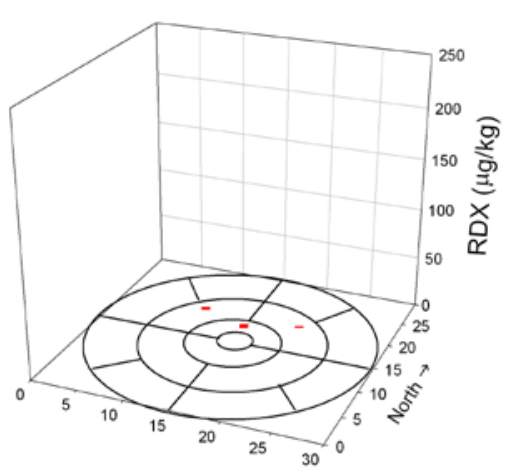

Site \#2 27Apr 2005

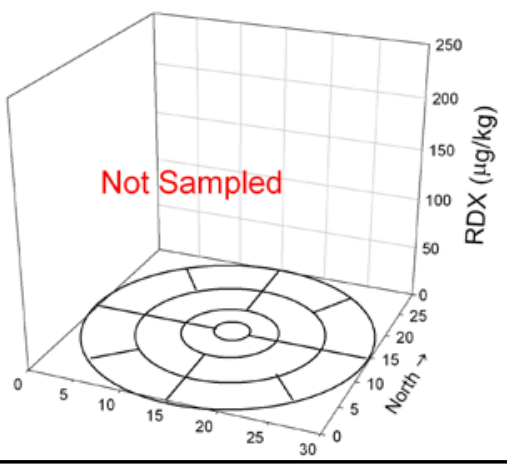

Site \#2 13Dec 2004

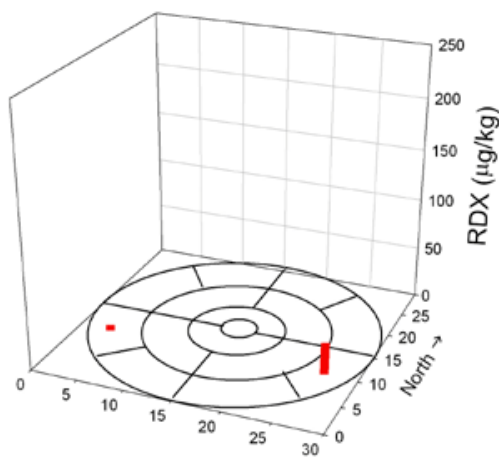

Site \#2 29Mar 2005

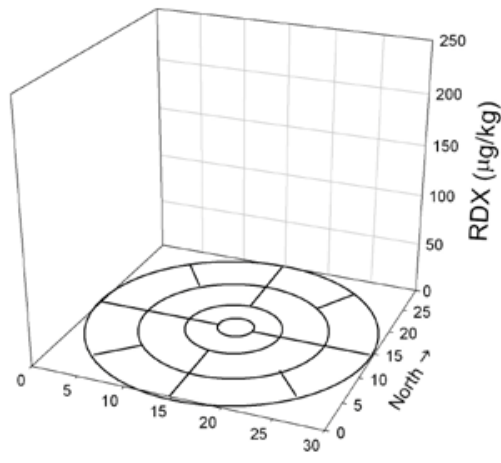

Figure A2. RDX concentrations at the soil surface on site \#2 (control). 


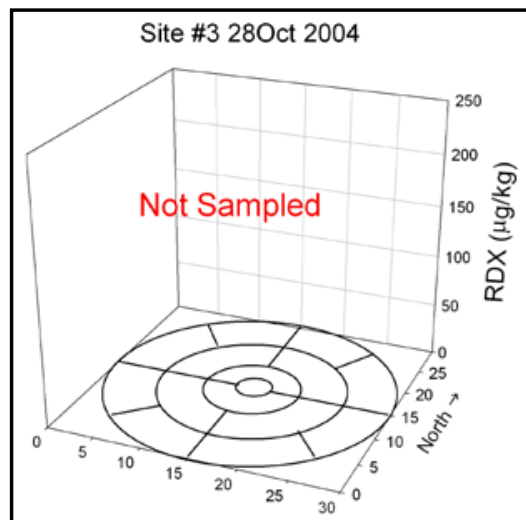

Site \#3 19Jan 2005

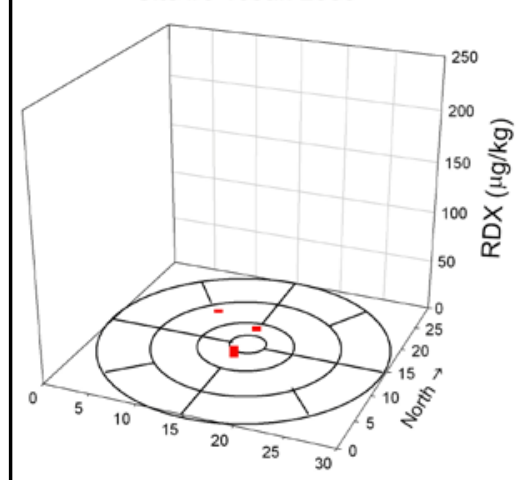

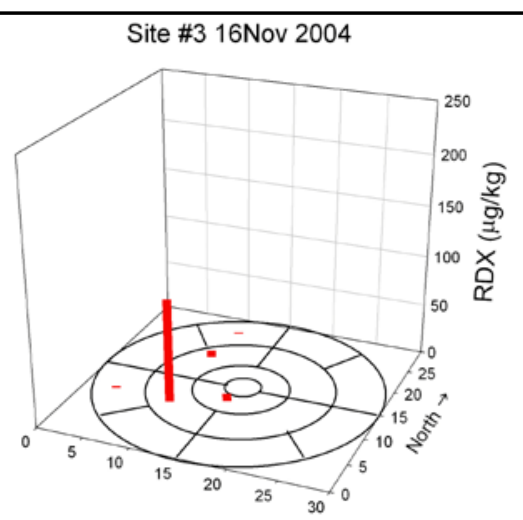

Site \#3 23Feb 2005

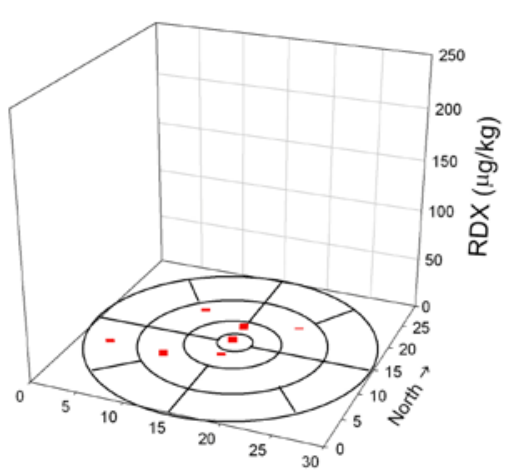

Site \#3 27Apr 2005

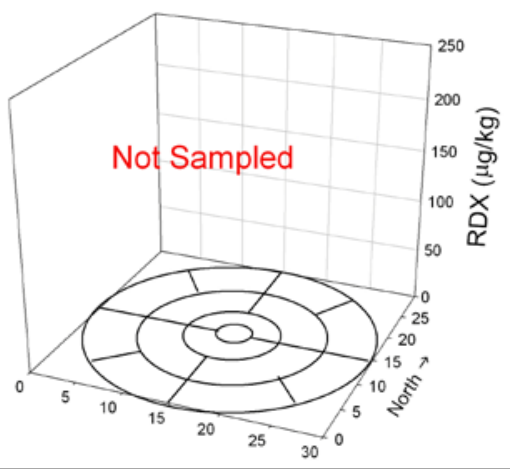

Site \#3 13Dec 2004

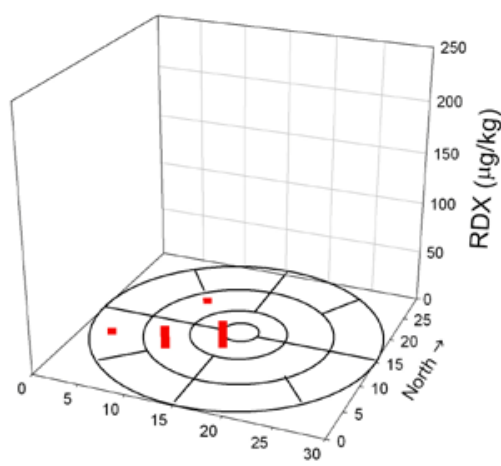

Site \#3 29Mar 2005

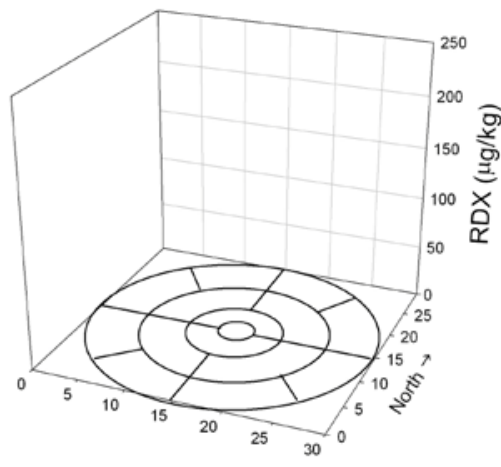




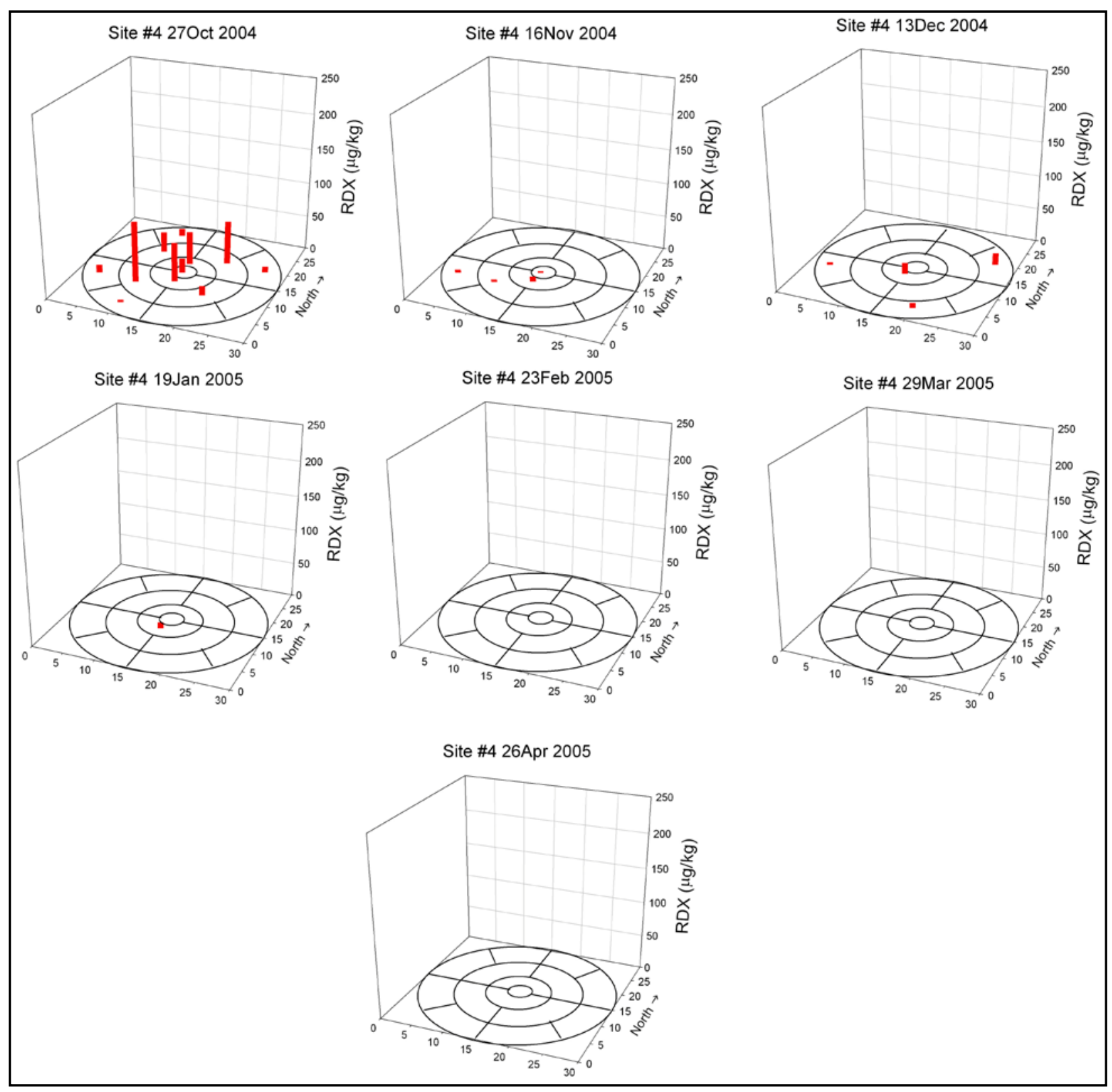

Figure A4. RDX concentrations at the soil surface on site \#4 (treated). 


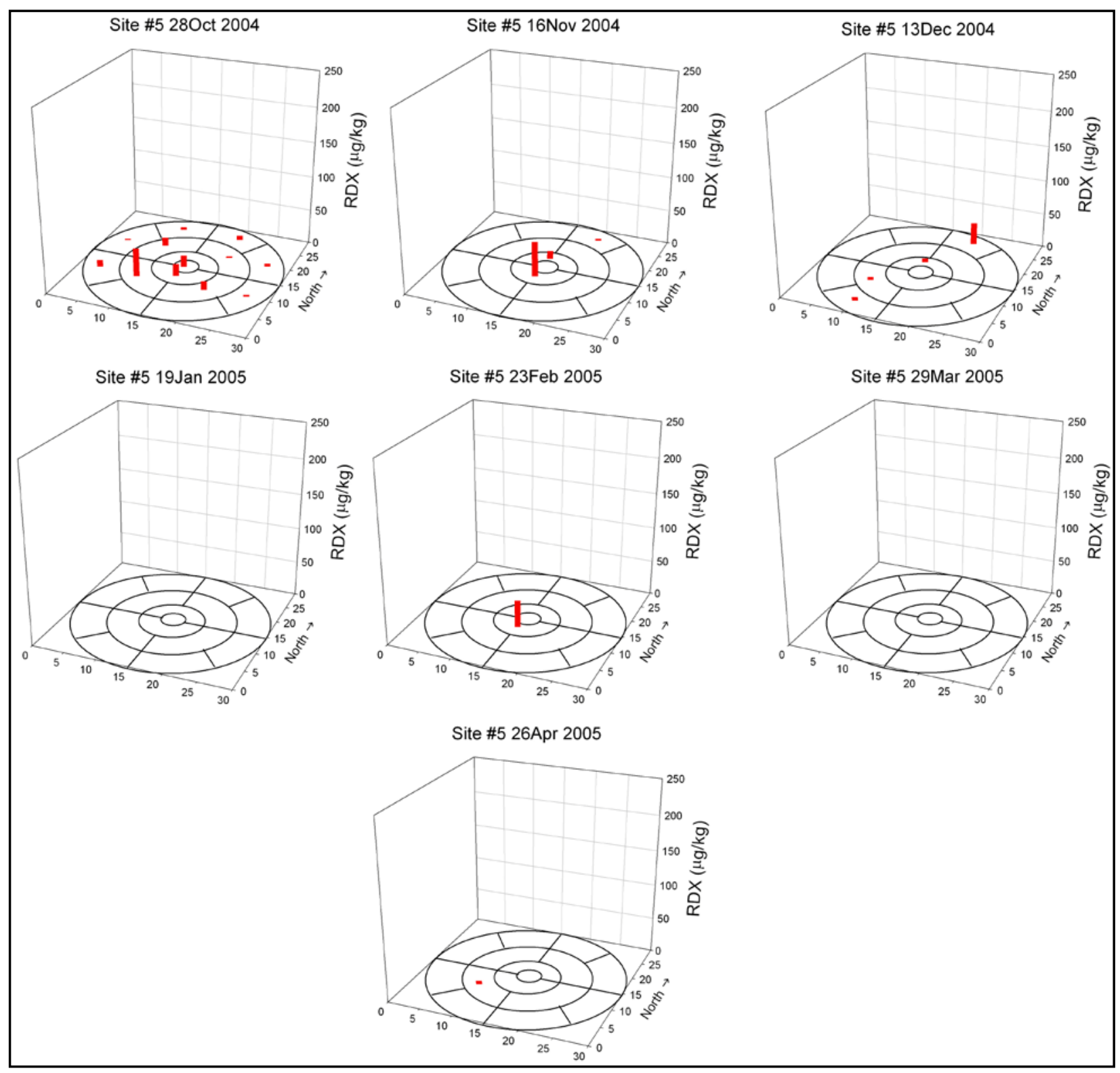

Figure A5. RDX concentrations at the soil surface on site \#5 (treated). 


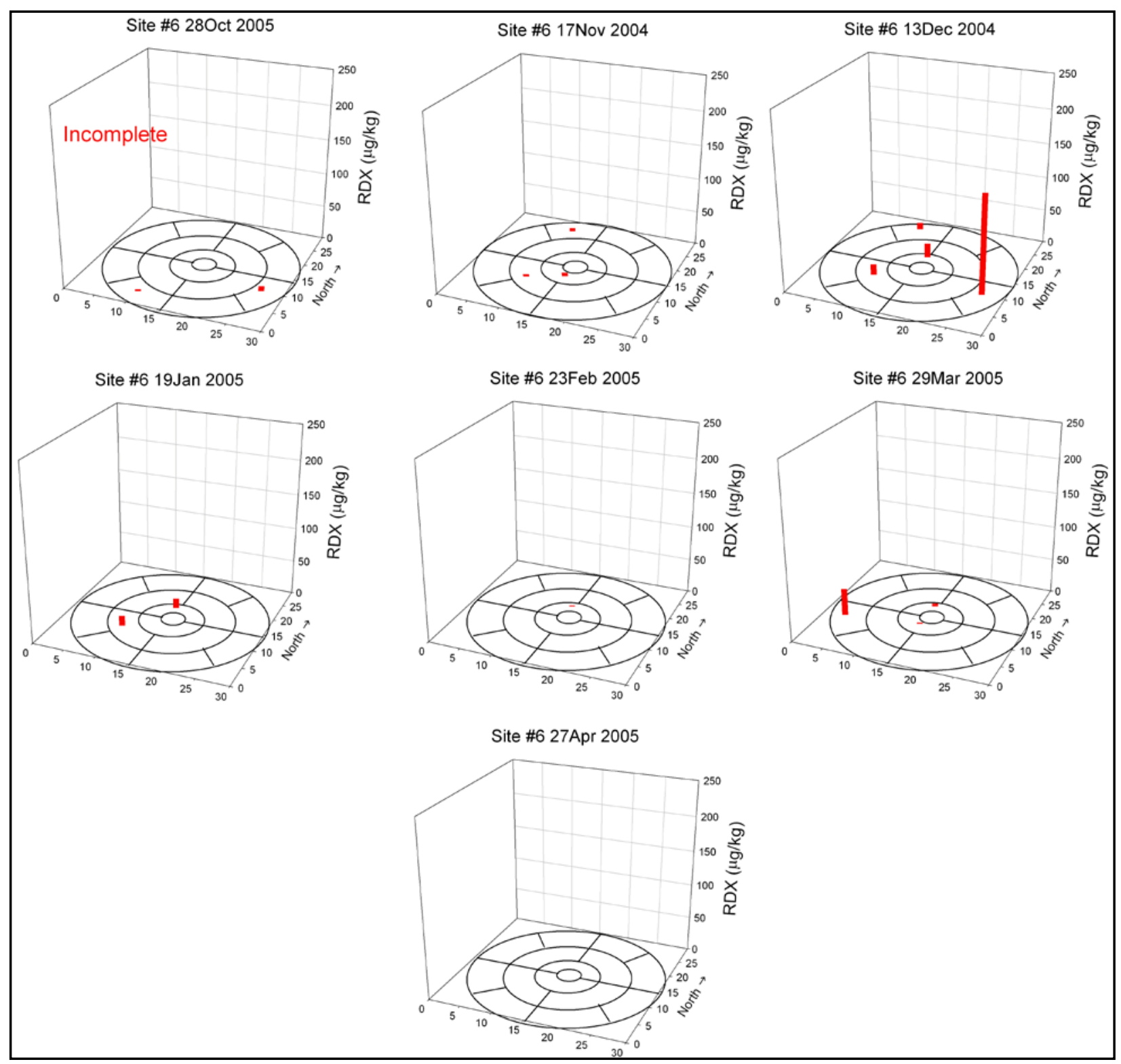

Figure A6. RDX concentrations at the soil surface on site \#6 (treated). 


\section{TNT Concentrations}

Table A14. TNT concentrations at the soil surface on site \#1 (control) by sampling area.

\begin{tabular}{|cccccccc|}
\hline & \multicolumn{7}{c|}{ Site \#1 } \\
Sample Area & $\mathbf{2 8 - O c t - 0 4}$ & 17-Nov-04 & 13-Dec-04 & 19-Jan-05 & 23-Feb-05 & 29-Mar-05 & 27-Apr-05 \\
1 & $<2.0$ & $<2.0$ & $<2.0$ & $<2.0$ & $<2.0$ & $<2.0$ & $<2.0$ \\
2 & 19.42 & $<2.0$ & $<2.0$ & $<2.0$ & $<2.0$ & $<2.0$ & $<2.0$ \\
3 & $<2.0$ & $<2.0$ & $<2.0$ & $<2.0$ & $<2.0$ & $<2.0$ & $<2.0$ \\
4 & 2.87 & $<2.0$ & 5.92 & $<2.0$ & $<2.0$ & $<2.0$ & $<2.0$ \\
5 & 6.35 & 2.32 & $<2.0$ & $<2.0$ & $<2.0$ & $<2.0$ & $<2.0$ \\
6 & $<2.0$ & $<2.0$ & $<2.0$ & $<2.0$ & $<2.0$ & $<2.0$ & $<2.0$ \\
7 & $<2.0$ & $<2.0$ & $<2.0$ & $<2.0$ & $<2.0$ & $<2.0$ & $<2.0$ \\
8 & $<2.0$ & $<2.0$ & $<2.0$ & $<2.0$ & $<2.0$ & $<2.0$ & $<2.0$ \\
9 & $<2.0$ & $<2.0$ & $<2.0$ & $<2.0$ & $<2.0$ & $<2.0$ & $<2.0$ \\
10 & $<2.0$ & $<2.0$ & $<2.0$ & $<2.0$ & $<2.0$ & $<2.0$ & $<2.0$ \\
11 & $<2.0$ & $<2.0$ & $<2.0$ & $<2.0$ & $<2.0$ & $<2.0$ & $<2.0$ \\
12 & $<2.0$ & $<2.0$ & $<2.0$ & $<2.0$ & $<2.0$ & $<2.0$ & $<2.0$ \\
13 & $<2.0$ & $<2.0$ & $<2.0$ & $<2.0$ & $<2.0$ & $<2.0$ & $<2.0$ \\
14 & 2.0 & $<2.0$ & $<2.0$ & $<2.0$ & $<2.0$ & $<2.0$ & $<2.0$ \\
15 & $<2.0$ & $<2.0$ & $<2.0$ & $<2.0$ & $<2.0$ & $<2.0$ & $<2.0$ \\
\hline
\end{tabular}

Table A15. TNT concentrations at the soil surface on site \#2 (control) by sampling area.

\begin{tabular}{|c|c|c|c|c|c|c|c|}
\hline \multirow{3}{*}{$\begin{array}{c}\text { Sample Area } \\
1\end{array}$} & \multicolumn{7}{|c|}{$\begin{array}{c}\text { Site \#2 } \\
\text { TNT Concentration at surface }(\mu \mathrm{g} / \mathrm{kg})\end{array}$} \\
\hline & 28-Oct-04 & 17-Nov-04 & 13-Dec-04 & 19-Jan-05 & 23-Feb-05 & 29-Mar-05 & 27-Apr-05 \\
\hline & & $<2.0$ & $<2.0$ & $<2.0$ & $<2.0$ & $<2.0$ & \\
\hline 2 & & $<2.0$ & $<2.0$ & $<2.0$ & $<2.0$ & $<2.0$ & \\
\hline 3 & & 2.44 & $<2.0$ & $<2.0$ & $<2.0$ & $<2.0$ & \\
\hline 4 & & $<2.0$ & $<2.0$ & $<2.0$ & $<2.0$ & $<2.0$ & \\
\hline 5 & & 2.55 & $<2.0$ & $<2.0$ & $<2.0$ & $<2.0$ & \\
\hline 6 & D & $<2.0$ & $<2.0$ & $<2.0$ & $<2.0$ & $<2.0$ & D \\
\hline 7 & 을 & $<2.0$ & $<2.0$ & $<2.0$ & $<2.0$ & $<2.0$ & 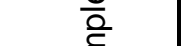 \\
\hline 8 & డ్ల్ & $<2.0$ & $<2.0$ & $<2.0$ & $<2.0$ & $<2.0$ & $\pi$ \\
\hline 9 & 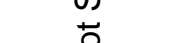 & $<2.0$ & $<2.0$ & $<2.0$ & $<2.0$ & $<2.0$ & 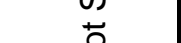 \\
\hline 10 & z & $<2.0$ & $<2.0$ & $<2.0$ & $<2.0$ & $<2.0$ & $\bar{z}$ \\
\hline 11 & & $<2.0$ & $<2.0$ & $<2.0$ & $<2.0$ & $<2.0$ & \\
\hline 12 & & $<2.0$ & 14.24 & $<2.0$ & $<2.0$ & $<2.0$ & \\
\hline 13 & & $<2.0$ & $<2.0$ & $<2.0$ & $<2.0$ & $<2.0$ & \\
\hline 14 & & $<2.0$ & $<2.0$ & $<2.0$ & $<2.0$ & $<2.0$ & \\
\hline 15 & & $<2.0$ & $<2.0$ & $<2.0$ & $<2.0$ & $<2.0$ & \\
\hline
\end{tabular}


Table A16. TNT concentrations at the soil surface on site \#3 (control) by sampling area.

\begin{tabular}{|c|c|c|c|c|c|c|c|}
\hline \multirow{3}{*}{$\begin{array}{c}\text { Sample Area } \\
1\end{array}$} & \multicolumn{7}{|c|}{ Site \#3 } \\
\hline & 28-Oct-04 & 17-Nov-04 & 13-Dec-04 & 19-Jan-05 & 23-Feb-05 & 29-Mar-05 & 27-Apr-05 \\
\hline & & $<2.0$ & $<2.0$ & $<2.0$ & $<2.0$ & $<2.0$ & \\
\hline 2 & & $<2.0$ & $<2.0$ & $<2.0$ & $<2.0$ & $<2.0$ & \\
\hline 3 & & $<2.0$ & $<2.0$ & $<2.0$ & $<2.0$ & $<2.0$ & \\
\hline 4 & & $<2.0$ & $<2.0$ & $<2.0$ & $<2.0$ & $<2.0$ & \\
\hline 5 & & $<2.0$ & $<2.0$ & $<2.0$ & $<2.0$ & $<2.0$ & \\
\hline 6 & 히 & 5.31 & $<2.0$ & $<2.0$ & $<2.0$ & $<2.0$ & ర్త \\
\hline 7 & 을 & $<2.0$ & $<2.0$ & $<2.0$ & $<2.0$ & $<2.0$ & 흘 \\
\hline 8 & స్ & $<2.0$ & $<2.0$ & $<2.0$ & $<2.0$ & $<2.0$ & ర్లీ \\
\hline 9 & \pm & $<2.0$ & $<2.0$ & $<2.0$ & $<2.0$ & $<2.0$ & $\hbar$ \\
\hline 10 & $z$ & $<2.0$ & $<2.0$ & $<2.0$ & $<2.0$ & $<2.0$ & $z$ \\
\hline 11 & & $<2.0$ & $<2.0$ & $<2.0$ & $<2.0$ & $<2.0$ & \\
\hline 12 & & $<2.0$ & 96.60 & $<2.0$ & $<2.0$ & $<2.0$ & \\
\hline 13 & & $<2.0$ & $<2.0$ & $<2.0$ & $<2.0$ & $<2.0$ & \\
\hline 14 & & $<2.0$ & $<2.0$ & $<2.0$ & $<2.0$ & $<2.0$ & \\
\hline 15 & & $<2.0$ & $<2.0$ & $<2.0$ & $<2.0$ & $<2.0$ & \\
\hline
\end{tabular}

Table A17. TNT concentrations at the soil surface on site \#4 (treated) by sampling area.

\begin{tabular}{|cccccccc|}
\hline & \multicolumn{7}{c|}{ Site \#4 } \\
Sample Area & 28-Oct-04 & 17-Nov-04 & 13-Dec-04 & 19-Jan-05 & 23-Feb-05 & 29-Mar-05 & 27-Apr-05 \\
1 & $<2.0$ & $<2.0$ & $<2.0$ & $<2.0$ & $<2.0$ & $<2.0$ & $<2.0$ \\
2 & $<2.0$ & $<2.0$ & $<2.0$ & $<2.0$ & $<2.0$ & $<2.0$ & $<2.0$ \\
3 & $<2.0$ & $<2.0$ & $<2.0$ & $<2.0$ & $<2.0$ & $<2.0$ & $<2.0$ \\
4 & $<2.0$ & $<2.0$ & $<2.0$ & $<2.0$ & $<2.0$ & $<2.0$ & $<2.0$ \\
5 & $<2.0$ & $<2.0$ & $<2.0$ & $<2.0$ & $<2.0$ & $<2.0$ & $<2.0$ \\
6 & 4.06 & $<2.0$ & $<2.0$ & $<2.0$ & $<2.0$ & $<2.0$ & $<2.0$ \\
7 & $<2.0$ & $<2.0$ & $<2.0$ & $<2.0$ & $<2.0$ & $<2.0$ & $<2.0$ \\
8 & $<2.0$ & $<2.0$ & $<2.0$ & $<2.0$ & $<2.0$ & $<2.0$ & $<2.0$ \\
9 & $<2.0$ & $<2.0$ & $<2.0$ & $<2.0$ & $<2.0$ & $<2.0$ & $<2.0$ \\
10 & $<2.0$ & $<2.0$ & $<2.0$ & $<2.0$ & $<2.0$ & $<2.0$ & $<2.0$ \\
11 & $<2.0$ & $<2.0$ & $<2.0$ & $<2.0$ & $<2.0$ & $<2.0$ & $<2.0$ \\
12 & $<2.0$ & $<2.0$ & $<2.0$ & $<2.0$ & $<2.0$ & $<2.0$ & $<2.0$ \\
13 & $<2.0$ & $<2.0$ & $<2.0$ & $<2.0$ & $<2.0$ & $<2.0$ & $<2.0$ \\
14 & $<2.0$ & $<2.0$ & $<2.0$ & $<2.0$ & $<2.0$ & $<2.0$ & $<2.0$ \\
15 & $<2.0$ & $<2.0$ & $<2.0$ & $<2.0$ & $<2.0$ & $<2.0$ & $<2.0$ \\
\hline
\end{tabular}


Table A18. TNT concentrations at the soil surface on site \#5 (treated) by sampling area.

\begin{tabular}{|cccccccc|}
\hline & \multicolumn{7}{c|}{ Site \#5 } \\
Sample Area & 28-Oct-04 & 17-Nov-04 & 13-Dec-04 & 19-Jan-05 & 23-Feb-05 & 29-Mar-05 & 27-Apr-05 \\
1 & $<2.0$ & $<2.0$ & $<2.0$ & $<2.0$ & $<2.0$ & $<2.0$ & $<2.0$ \\
2 & $<2.0$ & $<2.0$ & $<2.0$ & $<2.0$ & $<2.0$ & $<2.0$ & $<2.0$ \\
3 & 2.42 & $<2.0$ & $<2.0$ & $<2.0$ & $<2.0$ & $<2.0$ & $<2.0$ \\
4 & $<2.0$ & $<2.0$ & $<2.0$ & $<2.0$ & $<2.0$ & $<2.0$ & $<2.0$ \\
5 & $<2.0$ & $<2.0$ & $<2.0$ & $<2.0$ & $<2.0$ & $<2.0$ & $<2.0$ \\
6 & $<2.0$ & $<2.0$ & $<2.0$ & $<2.0$ & $<2.0$ & $<2.0$ & $<2.0$ \\
7 & 6.32 & $<2.0$ & $<2.0$ & $<2.0$ & $<2.0$ & $<2.0$ & $<2.0$ \\
8 & $<2.0$ & $<2.0$ & $<2.0$ & $<2.0$ & $<2.0$ & $<2.0$ & $<2.0$ \\
9 & $<2.0$ & $<2.0$ & 10.42 & $<2.0$ & $<2.0$ & $<2.0$ & $<2.0$ \\
10 & $<2.0$ & $<2.0$ & $<2.0$ & $<2.0$ & $<2.0$ & $<2.0$ & $<2.0$ \\
11 & $<2.0$ & $<2.0$ & $<2.0$ & $<2.0$ & $<2.0$ & $<2.0$ & $<2.0$ \\
12 & $<2.0$ & $<2.0$ & $<2.0$ & $<2.0$ & $<2.0$ & $<2.0$ & $<2.0$ \\
13 & $<2.0$ & $<2.0$ & $<2.0$ & $<2.0$ & $<2.0$ & $<2.0$ & $<2.0$ \\
14 & $<2.0$ & $<2.0$ & $<2.0$ & $<2.0$ & $<2.0$ & $<2.0$ & $<2.0$ \\
15 & $<2.0$ & $<2.0$ & $<2.0$ & $<2.0$ & $<2.0$ & $<2.0$ & $<2.0$ \\
\hline
\end{tabular}

Table A19. TNT concentrations at the soil surface on site \#6 (treated) by sampling area.

\begin{tabular}{|cccccccc|}
\hline \multicolumn{7}{c|}{ Site \#6 } \\
Sample Area & 28-Oct-04 & 17-Nov-04 & 13-Dec-04 & 19-Jan-05 & 23-Feb-05) & 29-Mar-05 & 27-Apr-05 \\
1 & \#N/A & $<2.0$ & $<2.0$ & $<2.0$ & $<2.0$ & $<2.0$ & $<2.0$ \\
2 & \#N/A & $<2.0$ & $<2.0$ & $<2.0$ & $<2.0$ & $<2.0$ & $<2.0$ \\
3 & \#N/A & 2.27 & $<2.0$ & $<2.0$ & $<2.0$ & $<2.0$ & $<2.0$ \\
4 & \#N/A & $<2.0$ & $<2.0$ & $<2.0$ & $<2.0$ & $<2.0$ & $<2.0$ \\
5 & \#N/A & $<2.0$ & $<2.0$ & $<2.0$ & $<2.0$ & $<2.0$ & $<2.0$ \\
6 & \#N/A & $<2.0$ & 2.0 & $<2.0$ & $<2.0$ & $<2.0$ & $<2.0$ \\
7 & \#N/A & $<2.0$ & $<2.0$ & $<2.0$ & $<2.0$ & $<2.0$ & $<2.0$ \\
8 & $<2.0$ & $<2.0$ & 139.60 & $<2.0$ & $<2.0$ & $<2.0$ & $<2.0$ \\
9 & $<2.0$ & $<2.0$ & $<2.0$ & $<2.0$ & $<2.0$ & $<2.0$ & $<2.0$ \\
10 & $<2.0$ & $<2.0$ & $<2.0$ & $<2.0$ & $<2.0$ & $<2.0$ & $<2.0$ \\
11 & \#N/A & $<2.0$ & $<2.0$ & $<2.0$ & $<2.0$ & $<2.0$ & $<2.0$ \\
12 & \#N/A & $<2.0$ & 65.00 & $<2.0$ & $<2.0$ & 6.53 & $<2.0$ \\
13 & $<2.0$ & $<2.0$ & $<2.0$ & $<2.0$ & $<2.0$ & $<2.0$ & $<2.0$ \\
14 & $<2.0$ & $<2.0$ & $<2.0$ & $<2.0$ & $<2.0$ & $<2.0$ & $<2.0$ \\
15 & $<2.0$ & $<2.0$ & 51.60 & $<2.0$ & $<2.0$ & $<2.0$ & $<2.0$ \\
\hline
\end{tabular}




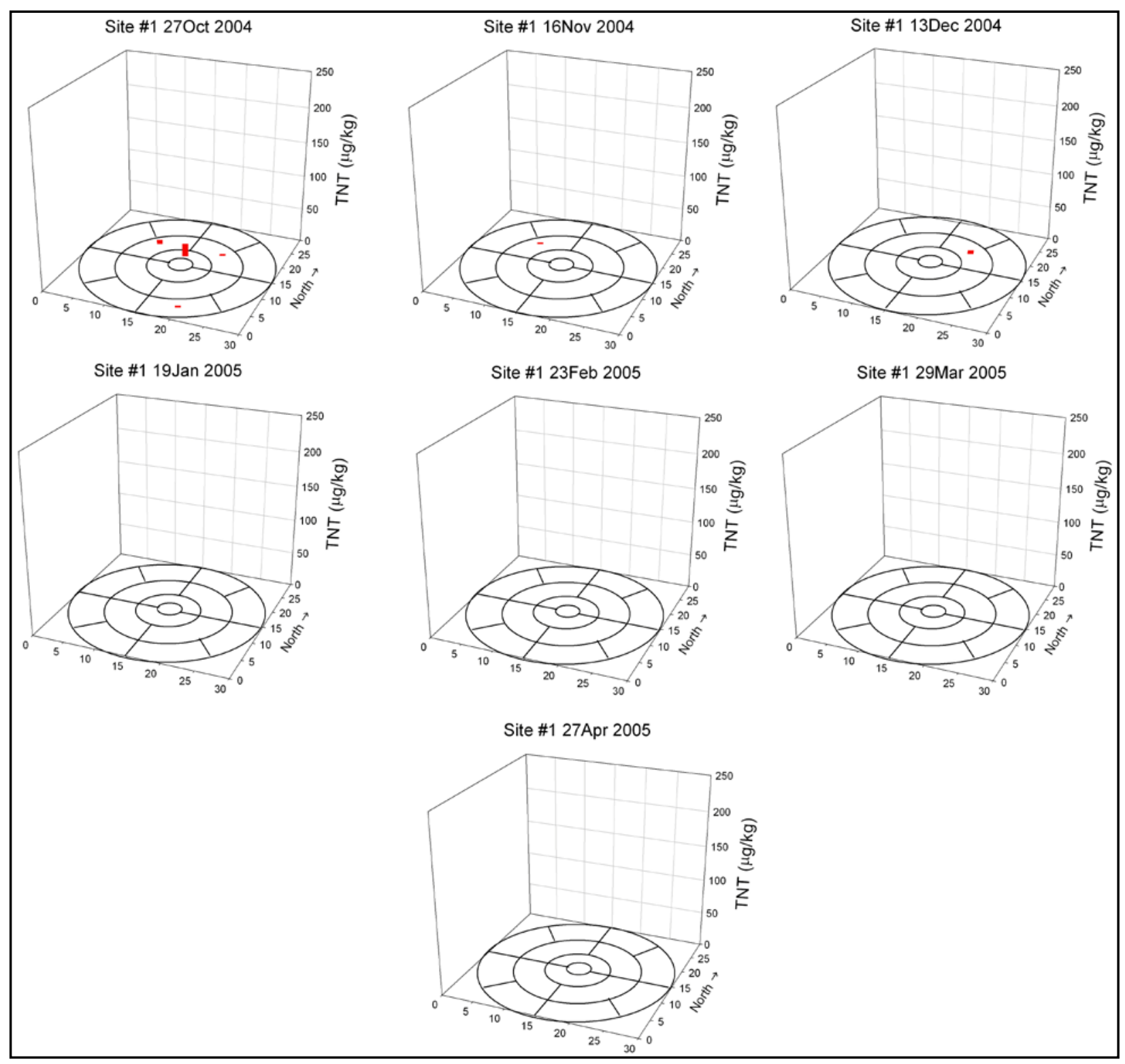

Figure A7. TNT concentrations at the soil surface on site \#1 (control). 


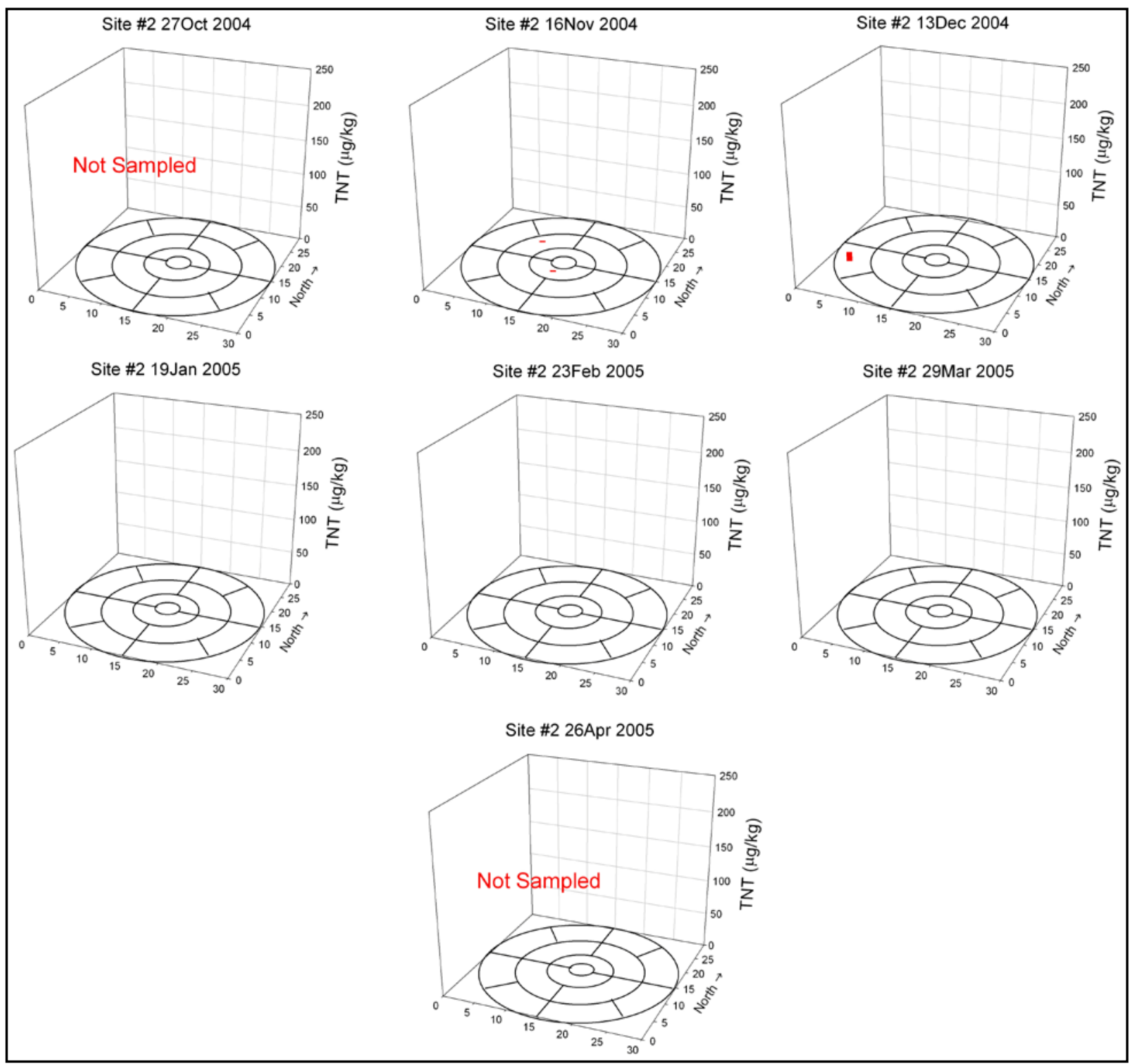

Figure A8. TNT concentrations at the soil surface on site \#2 (control). 


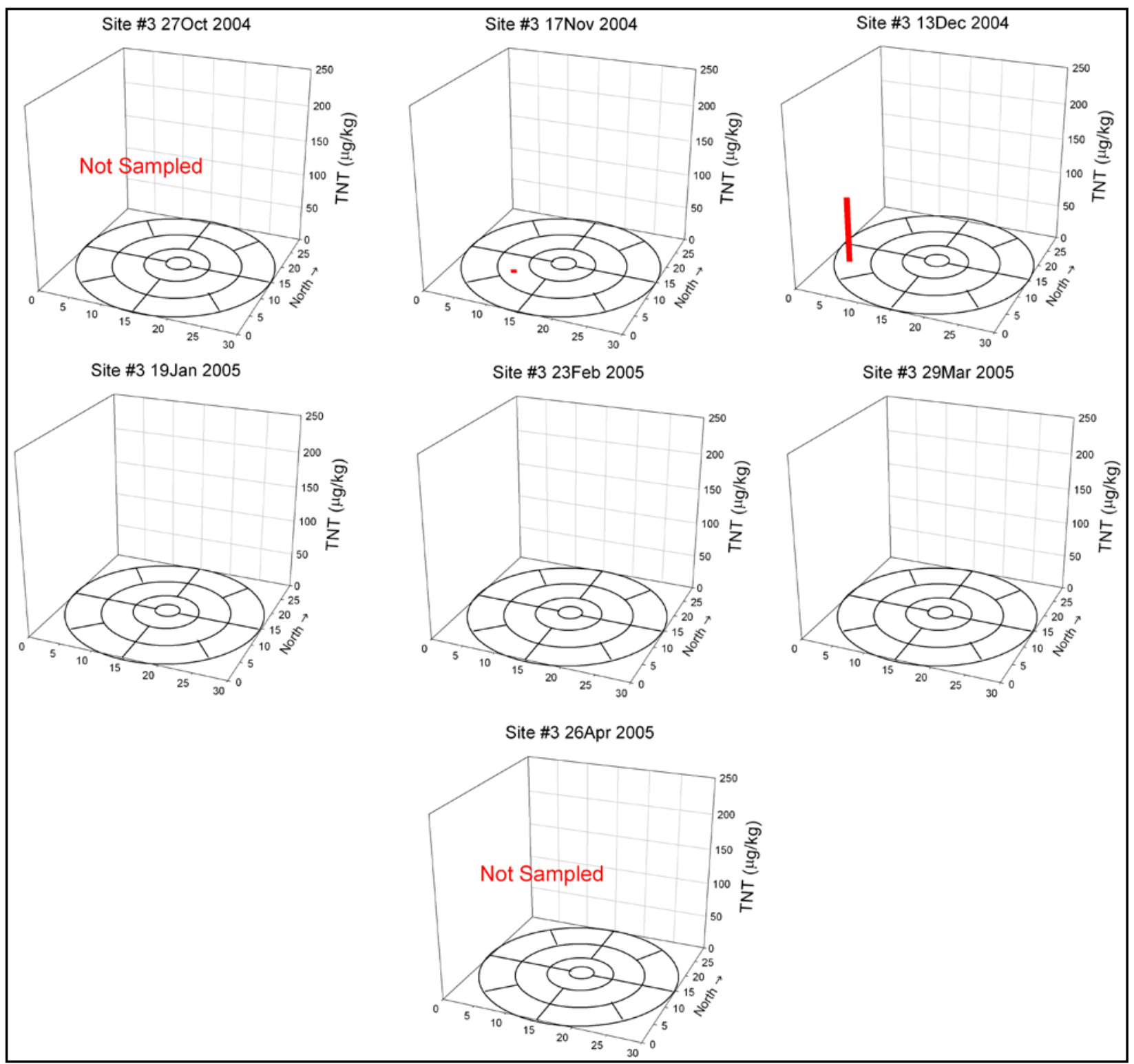

Figure A9. TNT concentrations at the soil surface on site \#3 (control). 


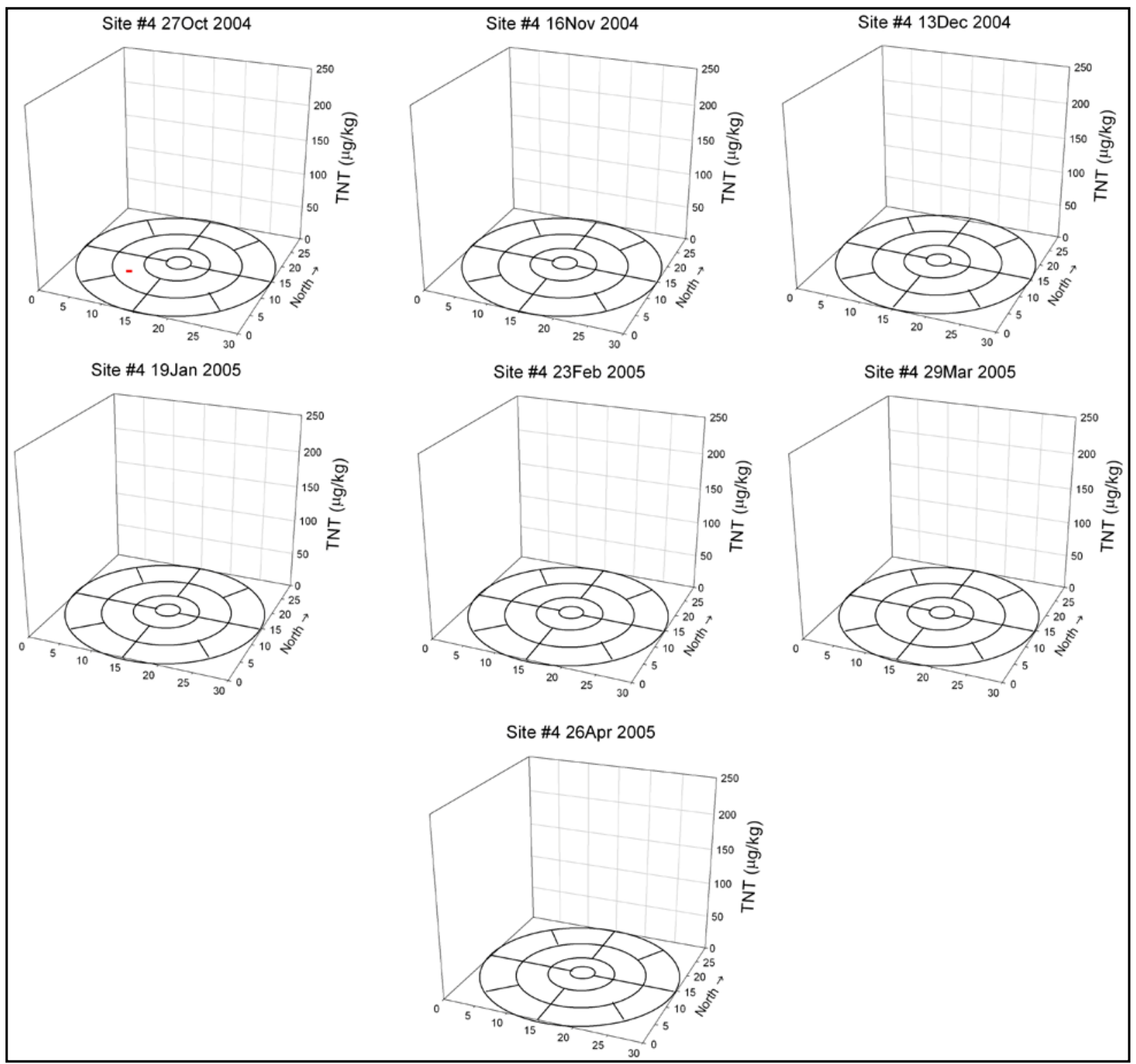

Figure A10. TNT concentrations at the soil surface on site \#4 (treated). 


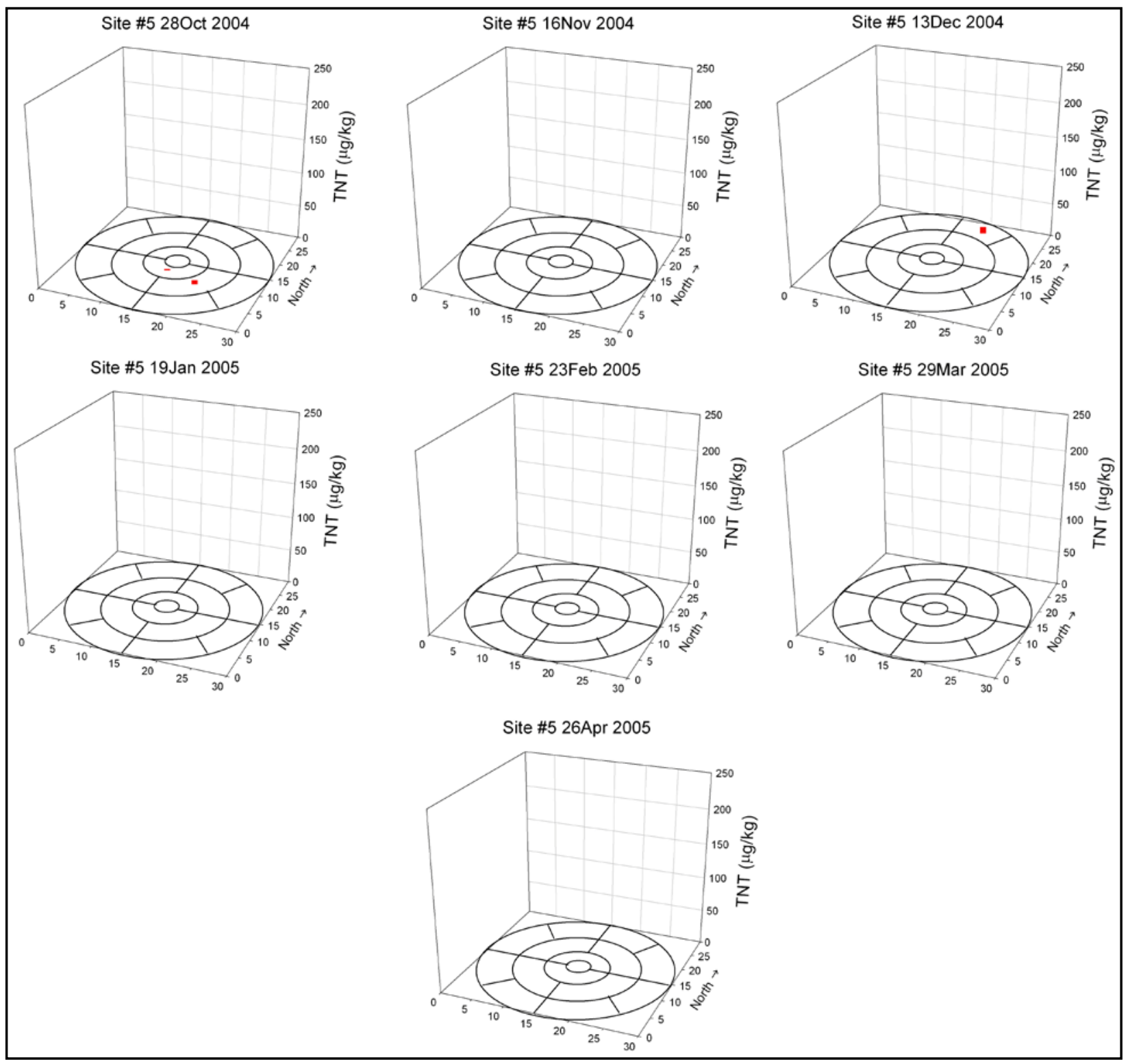

Figure A11. TNT concentrations at the soil surface on site \#5 (treated). 


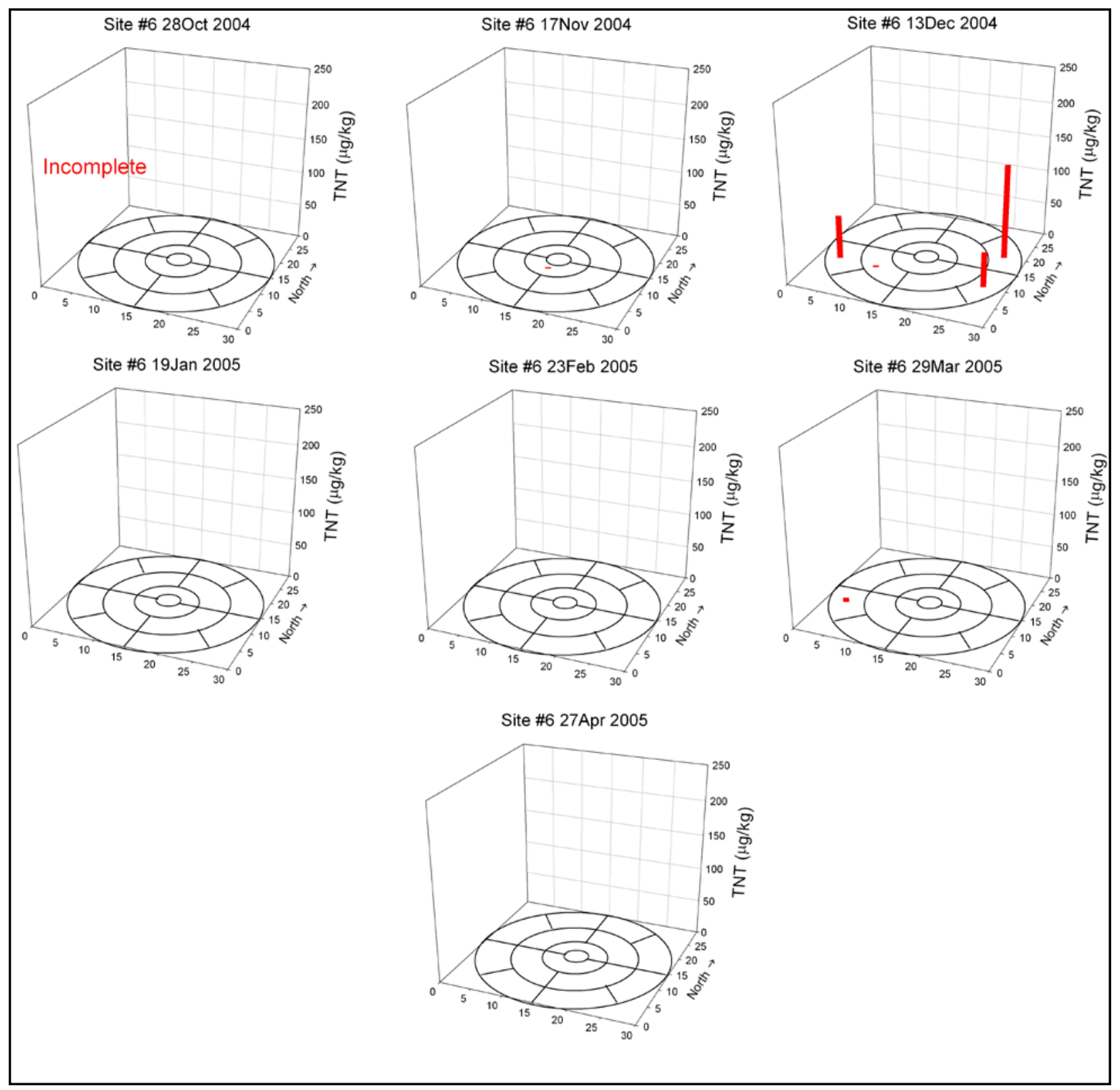

Figure A12. TNT concentrations at the soil surface on site \#6 (treated). 


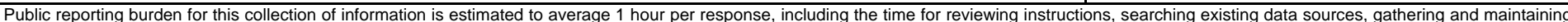

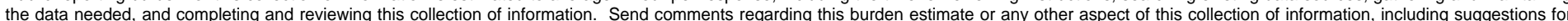

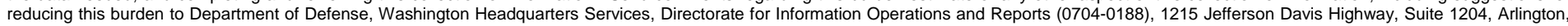

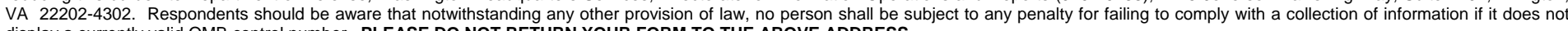
display a currently valid OMB control number. PLEASE DO NOT RETURN YOUR FORM TO THE ABOVE ADDRESS.

\begin{tabular}{l|l}
$\begin{array}{l}\text { 1. REPORT DATE (DD-MM-YYYY) } \\
\text { June } 2010\end{array}$ & $\begin{array}{c}\text { 2. REPORT TYPE } \\
\text { Final report }\end{array}$ \\
\hline
\end{tabular}

\section{TITLE AND SUBTITLE}

Topical Lime Application for the Management of Munitions Constituents Following Blow-In-Place Operations

3. DATES COVERED (From - To)

5a. CONTRACT NUMBER

5b. GRANT NUMBER

5c. PROGRAM ELEMENT NUMBER

5d. PROJECT NUMBER

5e. TASK NUMBER

5f. WORK UNIT NUMBER

8. PERFORMING ORGANIZATION REPORT NUMBER

ERDC/EL TR-10-10

Environmental Laboratory, U.S. Army Engineer Research and Development Center, 3909 Halls Ferry Road, Vicksburg, MS 39180-6199;

Applied Research Associates, 112 Monument Place, Vicksburg, MS 39180

9. SPONSORING / MONITORING AGENCY NAME(S) AND ADDRESS(ES)

10. SPONSOR/MONITOR'S ACRONYM(S)

11. SPONSOR/MONITOR'S REPORT NUMBER(S)

\section{DISTRIBUTION / AVAILABILITY STATEMENT}

Approved for public release; distribution is unlimited.

\section{SUPPLEMENTARY NOTES}

\section{ABSTRACT}

Blow-in-place operations provide a proven method of handling unexploded ordnance, but they also deliver significant amounts of munitions constituents residues to the environment. These residues may persist and affect environmental sustainability on training ranges. Alkaline hydrolysis is a well-established method for the destruction of explosives compounds. The objective of this study was to measure the efficacy of on-site treatment of munitions constituents with hydrated lime following blow-in-place operations. Samples taken immediately following topical application of hydrated lime demonstrate that lime does have an immediate effect on RDX concentration. However, munitions constituents residues unaffected by lime treatment remained at the end of the study, probably because of poor contact between munitions constituents residues and hydrated lime. This study highlighted three challenges to consider as technology development moves forward on alkaline treatment of munitions constituents. First, inconsistent RDX concentrations obscured the results of the field study. Second, the application method will make an important impact on the success of the treatment. Finally, application rates will need to be tailored to individual applications so that enough alkaline material is delivered to effect complete destruction of the munitions constituent residues of concern.

\section{SUBJECT TERMS}

$\begin{array}{ll}\text { Alkaline hydrolysis } & \text { Munitions residues } \\ \text { Blow-in-place operations } & \text { RDX }\end{array}$

\section{SECURITY CLASSIFICATION OF:}

\section{a. REPORT}

UNCLASSIFIED

b. ABSTRACT
UNCLASSIFIED

c. THIS PAGE

UNCLASSIFIED 17. LIMITATION
OF ABSTRACT

18. NUMBER OF PAGES

50 19a. NAME OF RESPONSIBLE PERSON

19b. TELEPHONE NUMBER (include area code) 